\title{
Coleções etnográficas, método de convergência e etnografia da duração: um espaço de problemas.
}

\author{
Ana Luiza Carvalho da Rocha
}

\section{O método de convergência e etnografia da duração}

$\mathrm{O}$ método de convergência ${ }^{1}$ no interior da obra de Gilbert Durand aponta para alguns temas específicos a serem aqui mencionados como provocações de um estudo para o caso do BIEV com a produção e geração de coleções etnográficas como parte da pesquisa com etnografia da duração ${ }^{2}$ no âmbito das modernas sociedades complexas, urbano-industriais.

Inicialmente, este método é apontado por G. Durand, desde as reflexões de H. Bergson em sua obra La Pensée et le Mouvant ${ }^{3}$ como forma singular do autor desenvolver seus estudos sobre as estruturas antropológicas do Imaginário. Tal método se circunscreve, portanto, dentro do estruturalismo figurativo de matriz durandiana onde as formas das imagens desempenham um papel menor na sua classificação como coleções por oposição as estruturas em termos do dinamismo transformador que as imagens contemplam no campo do Imaginário e da imaginação criadora.

No âmbito do estruturalismo figurativo a interpretação das formas decorre da associação entre o devaneio e a matéria através da qual uma forma se dá a ver, tornando-se, assim, potencia interpretativa da própria imagem. Antes de ser espetáculo da consciência humana as formas que adotam uma imagem expressam os traços que os sonhos e os devaneios daquele que imagina o mundo. A imagem, portanto, contempla ação e pensamento sobre o mundo.

No contexto da dinâmica da imaginação situa-se, assim, igualmente a produção da imagem que o antropólogo constrói do mundo do outro e de si através da escrita ou de outros recursos de construção da representação etnográfica. A produção antropológica como parte da obra humana e como integrante dos fenômenos da cultura e das sociedades não pode prescindir das imagens, expressa nas formas de narrativas, nos gestos, nas posturas, nos artefatos, nos objetos, etc. daquilo que ele pratica como oficio.

\footnotetext{
${ }^{1}$ Cf. G. DURAND, Les structures anthropologiques de l'imaginaire, Paris, Dunod, 1984

${ }^{2}$ A propósito ver o artigo de C. ECKERT \& A.L.C da ROCHA Imagens do tempo: por uma etnografia da duração. In: O tempo e a cidade. Coleção Academia II. Porto Alegre, Ed. da UFRGS, 2005. Termo cunhado a partir da leitura inspiradora da ritmanálise na obra de G. BACHELARD, La dialéctique de la durée. Paris, PUF, 1963.

${ }^{3}$ Ver a respeito H. BERGSON, La Pensée et le Mouvant, Paris, PUF, 1969b, onde o autor assinala o lugar da intuição como auscultação ou apalpação em profundidade do conhecimento, ou seja, através das coincidências entre imagens diversas associadas a ordens de coisas diferentes cuja convergência de suas ações podem dirigir a consciência para um ponto preciso onde ela pode intuir um conhecimento.
} 
No estruturalismo figurativo de G. Durand ${ }^{4}$, o social transcorre em construção permanente através de dispositivos simbólicos substancializados em processos ricos de sentido, os quais convocam o tempo passado como explicação do tempo presente pela presença de invariantes e onde se conjuga a memória como veiculo de significados diferentes que o presente convoca em relação aos mesmos significantes. E, para o caso dos estudos de representação sociais e culturais que estão presentes no estudo de coleções, o estruturalismo figurativo reconhece invariâncias de determinados dispositivos (os grandes eixos do imaginário ${ }^{5}$ ), as quais apontam para um substantivo simbólico central que é a permanência do arcaico (a matriz dos gestos e das pulsões primárias) na dinâmica das transformações das sociedades humanas. Não se trata de reduzir ao substantivo simbólico arcaico o sentido imediato aos atos humanos, mas ao contrario, pensa-lo o deslocamento (acomodação-assimilação, em Piaget ${ }^{6}$, e extraversão-introversão, em Bachelard ${ }^{7}$ ) de tais gestos e pulsões no interior do próprio corpo coletivo que por sua, desloca-se no tempo e no espaço. Este processo o autor descreve como o trajeto antropológico que orienta o processo de intercambio incessante (gênese recíproca, cf. G. Durand ${ }^{8}$ ) no plano do imaginário, entre pensamento e matéria, o sentido e as coisas, o mundo das idéias e o mundo dos objetos, as pulsões subjetivas e as intimações objetivas. O trajeto antropológico traduz o universo por excelência das imagens e o simbolismo imaginário como parte integrante da dialética que funda a coerência entre o sentido e o símbolo na construção da homogeneidade da representação.

Em termos dos estudos de memória coletiva desde a etnografia da duração o método de convergência, criado por H. Bergson e revisto por G. Durand (à luz dos estudos de A. LeroiGouhran, G. Bachelard, J. Piaget), estabelece alguns parâmetros para a pesquisa antropológica em sociedades complexas.

Primeiramente o fato de que se torna evidente, neste processo, que não se trata de uma etnografia cujo sentido autoral reside na figura do antropólogo, mas no grau de imersão do antropólogo nos jogos da memória do outro. Em segundo lugar, este autor advoga, tal como G.

\footnotetext{
${ }^{4}$ Cf. G. DURAND, Figures mythiques et visages de l'oeuvre. Paris, Berg International, 1979; Beaux-Arts et archétypes, la religion de l'art, Paris PUF, 1989.

${ }^{5}$ Ver a respeito o conceito mencionado na obra de G. DURAND, Les structures anthropologiques de l'imaginaire, Paris, Dunod, 1984, p.41.

${ }^{6}$ Cf. J. PIAGET Introdução a psicologia genética e Filosofia, ilusões da sabedoria, da Coleção os Pensadores, Ed. Abril, São Paulo, 1978.

${ }^{7} \mathrm{Cf}$. La terre et les revêries du repos e La terre et les rêveries de la volonté, Paris, José Corti, 1988, ambas obras de G. BACHELARD.

${ }^{8}$ Ver a respeito o conceito mencionado por G. DURAND, Les structures anthropologiques de l'imaginaire, Paris, Dunod, 1984, p.38.
} 
Vergnaud $^{9}$, J. Piaget ${ }^{10}$, H. Wallon ${ }^{11}$, Sara Paín ${ }^{12}$ entre outros pesquisadores da psicologia da inteligência, que a imaginação criadora participa da construção do pensamento intelectual produzido no interior do campo dos saberes científicos. Em terceiro, o método de convergência reconhece a espessura das camadas temporais que representam os jogos da memória coletiva e que orientam, no seu intimo, os arranjos das lembranças. Quarto ponto, esta abordagem do método de convergência para a produção e geração de coleções etnográficas reforça o que já vimos insistindo há algum tempo, na figura do antropólogo como narrador ${ }^{13}$ no interior dos processos de construção da representação etnográfica pelo pensamento antropológico ${ }^{14}$. Por ultimo, e não menos importante, o método de convergência acaba reconhecendo o que $\mathrm{H}$. Wallon dirá mais tarde, em seus estudos sobre as origens do pensamento na criança, de que para se operar um conceito necessitamos atingir o patamar de um pensamento por rede, derivado de outras formas de pensar através de processos de construção de constelações, de séries e de duplas.

Entre os usos do método de convergência feitos por G. Durand, no interior do estruturalismo figurativo, e aquele promovido por H. Bergson, na sua obra Pensée et Mouvant, é necessário se ter em mente alguns processos de ruptura epistemológica na forma do tratamento interpretativo do Tempo e de sua matéria perecível, em seu ciclo eterno de renascimento e morte, de dissolução e recriação, para os estudos de memória coletiva e patrimônio etnológico para o que nos interessa que é a etnografia da duração nas modernas sociedades complexas, urbano-industriais. Neste sentido repousa a originalidade do pensamento de $\mathrm{H}$. Bergson e no seu método de convergência que é o de revelar a complexidade da construção real (e das relações entre matéria e memória) ao se interrogar se, desde as diversas regiões da experiência humana, de um determinado conjunto de imagens diversas oriundos de ordens de coisas diferentes e heterogêneas a consciência poderia intuir um sentido desde a presença de convergência de um sentido entre eles, o qual poderá, por derivação, convergir para o conhecimento de outros fatos similares entre si. Segundo este autor, grupos diferentes de imagens heterogêneas ainda que não possa nos fornecer conhecimento suficiente sobre um determinado fenômeno, podem trazer à consciência, entretanto, a direção para este conhecimento. Quanto mais imagens reunidas, mais direções para a consciência acessar, através da intuição, o seu conhecimento, tais imagens reúnem assim numerosas linhas de fatos que podem ser

\footnotetext{
${ }^{9}$ Cf. G. VERGNAUD, A formação dos conceitos científicos, In: O fio e a rede do equilibrista, Porto Alegre, Ed.Geempa, 1993.

${ }^{10}$ Cf. J. PIAGET, A formação no símbolo na criança, A construção do real na criança, O nascimento da inteligência na criança, Rio de Janeiro, Zahar Editores, 1970

${ }^{11}$ Cf. WALLON, H. , Les origines de la pensée chez l'enfant, Paris, PUF, 1975.

${ }^{12}$ Cf. S. PAIN, A função da ignorância, Porto Alegre, Artes Médicas, 1999.

${ }^{13}$ Cf. artigo de C. ECKERT \& A.L.C da ROCHA, O antropólogo na figura do narrador . In: O tempo e a cidade. Coleção Academia II. Porto Alegre, Ed. da UFRGS, 2005.

${ }^{14}$ Cf. artigo de C. ECKERT \& A.L.C da R,OCHA A interioridade da experiência temporal como condição da produção etnográfica. In: O tempo e a cidade. Coleção Academia II. Porto Alegre, Ed. da UFRGS, 2005.
} 
prolongados hipoteticamente tanto quanto se queira, sem, entretanto, tomá-los isoladamente. O método de convergência batizado por $\mathrm{H}$. Bergson considera que as imagens na modalidade de conjuntos, por suas convergências, pode nos conduzir a certos conhecimentos sobre o mundo. Neste sentido, o método de convergência não poderia ser uma obra de um individuo sozinho, mas se comporia, sim, como obra coletiva, através de uma colaboração entre muitos indivíduos.

O que esta por detrás deste método para o pensamento bergsoniano do tempo é o reconhecimento de que o tempo real tanto quanto a sua própria passagem sempre nos escapa, ou seja, sua representação é sempre indireta (ainda que o autor confunda aqui a imagem da coisa imagem-lembrança, e o duplo mnésico da percepção) além de alerta de que o continuum da consciência humana reside na produção de conexões imaginativas. Algo que pode ser transladado para o caso da interpretação da representação etnográfica escrita ou audiovisual, produzidas pelo antropólogo em seu trabalho de campo ou gerada no interior das praticas culturais humanas e nas formas expressivas que elas adotam. Ou seja, toda a complexidade do real das imagens que uma descrição etnográfica pretende expressar assim como o efeito de continuum que a representação etnográfica apenas revela indiretamente nas regiões diversas da experiência humana do etnógrafo no mundo do outro a partir do próprio encontro etnográfico com este outro. E no caso da obra etnográfica, escrita ou audiovisual, ainda que as imagens produzidas pelos antropólogos possam ser tomadas isoladamente, o que $\mathrm{H}$. Bergson ensina é que o efeito de convergência como forma de conhecê-las só se obtém se as considerarmos como uma totalidade.

\section{Método de convergência, classificação de formas e estruturas figurativas}

Migrando-se da forma original do método de convergência, vamos ingressar na re-leitura de G. Durand deste método. Em termos da classificação das formas e das estruturas figurativas que tais as imagens contemplam, para a arqueologia antropológica de G. Durand, trata-se de construir, através do método de convergência, uma classificação de símbolos os quais constelam em torno de um mesmo tema arquetipal, segundo a equivalência de suas formas (equivalência morfológica), ou seja, das imagens cuja materialidade dos seus elementos se parecem. Neste ponto, G. Durand esclarece sua distancia do estruturalismo lévi-straussiano, não se trata de uma convergência de imagens por analogia (equivalência funcional), ou seja, de acordo que a função que uniria a materialidade dos elementos de imagens diversas.

Portanto, o método de convergência é acrescido aqui de toda uma preocupação do estruturalismo figurativo de G. Durand com o estudo das estruturas antropológicas do imaginário a partir da convergência (simbólica) de imagens (e suas variações) em núcleos semânticos organizadores de sentido, no interior de constelações. O método de convergência amplificado pela 
leitura bachelardiana da imaginação criadora de G. Durand traduziria o dinamismo organizacional destas imagens segundo o semantismo dos símbolos que elas carregam, tema de investigação que a arqueologia antropológica durandiana se dedica a compreender como parte das manifestações humanas da imaginação. ${ }^{15}$ Apoiando-se no método de convergência, as formas das imagens expressam um dinamismo criador inesgotável pelas motivações simbólicas do gesto humano que elas encerram, numa gênese recíproca de acomodação-assimilação das pulsões subjetivas humanas as intimações objetivas do mundo cósmico e social. E por esta via, rompendo com a idéia da imaginação como um resíduo a posteriori, as imagens traduzem objetivamente a complexidade dos dados externos do real à subjetividade que perpassa a consciência imaginante humana.

Interessa aqui ressaltar o método de convergência como micro-comparativo em que a se procura reunir a dispersão antropológica das imagens reunidas numa coleção desde seus materiais e suportes diversos num conjunto de imagens segundo séries e constelações, conforme o caráter simultâneo de dois aspectos de sua conformação: o estático, onde podemos observar as imagens reunidas em núcleos conforme certos pontos de condensação simbólica, cristalizando-se em certas formas (um pensamento que pensa algo), e o cinemático, ou seja, resultado de schèmes (expressão do próprio movimento de um pensamento que se pensa pensando algo) ${ }^{16}$. Entretanto, estes dois aspectos não se podem ser interpretados isoladamente posto que eles se apresentam no interior de uma narrativa (récit) e/ou discurso que atua como fio que une as constelações e as séries de imagens desde um sentido agenciado pelos símbolos.

Em se tratando de uma investigação sobre o pluralismo empírico do meio cósmico e social das sociedades moderno-contemporâneas, empregando-se este termo durandiano, trata-se de se pensar as censuras culturais e as intimações sociais que as orientam para uma seleção de certas formas simbólicas para a construção de seus modelos de construção do real no âmbito dos jogos de sua memória coletiva. As imagens são portadoras das motivações simbólicas de um corpo coletivo e, segundo expressão durandiana, degradam-se em formas (literárias, fotográficas, fílmicas, sonoras, gráficas, etc.) cuja força de sentido traduzem para elas uma direção. Entretanto, as imagens possuem, em seu nascedouro, um caráter dominante (imperialismo das imagens), agindo como principio de organização (estrutura): os gestos e as pulsões e a matéria do ambiente técnico (cósmico e social) sobre a qual a imaginação criadora humana se deposita.

No jogo entre universalidade e particularidades resultam as imagens como num acordo entre natureza e cultura para que um conteúdo cultural, configurado em determinadas formas, possa ser transmitido e perpetuado no tempo e no espaço como algo de ordem de uma determinada sociedade.

\footnotetext{
${ }^{15}$ Cf. G. DURAND, L'imagination symbolique, Paris, PUF, 1992, p. 41.

${ }^{16}$ A propósito ver a diferença entre schème e schema (esquema) em J. Piaget, mencionado em nota de rodapé por G. DURAND, em sua obra Les strcutures anthropologiques de l'imaginaire.
} 
As imagens resultam de motivações simbólicas frutos de acordos, e não como falta. As classificações das imagens têm estreita relação com a historia das representações simbólicas de objetos, técnicas e materiais, mas não se reduz as motivações veiculadas por um ambiente técnico e material de uma dada ordem social e cósmica, bem ao contrario, são estas imagens que o consolida como real. Portanto, para G. Durand ${ }^{17}$, toda a imagem simbólica, nestes termos, é simbólica e não semiológica por integrar uma função fantástica. Transladando para o que nos importa aqui como pesquisa com imagens, e imagens inclusive de acervos os mais diversos, a uma anterioridade cronológica e ontológica do simbolismo de uma imagem antes de toda e qualquer factualidade da significação audiovisual, cuja característica central é a forma de exprimir ou enunciar o Cogito sonhador daquele que a fabrica.

Para as investigações sobre memória coletiva e patrimônio etnológico no interior do BIEV sobre o tema das coleções etnográficas, formas de sociabilidades e itinerários urbanos no mundo contemporâneo, o estruturalismo figurativo de G. Durand dialoga com os estudos da forma e da imagem em dois outros autores de forte inspiração bachelardiana no estudo da imaginação e do imaginário que são Pierre Sansot (discípulo direto de G. Bachelard, como G. Durand) e seus estudos sobre a poética das formas da cidade e M. Maffesoli (discípulo direto de G. Durand, este discípulo direto de G. Bachelard) e seus estudos sobre a imagem, o formismo simeliano e as socialidades contemporâneas. O que reúne as obras destes autores aos temas de investigação do BIEV em suas pesquisas antropológicas na cidade a partir da produção sonora, visual e escrita de etnografias na cidade é que estamos operando com o estudo das imagens através das investigações das formas narrativas que elas adotam para o viver a cidade para seus habitantes tanto quanto para o antropólogo ${ }^{18}$. Ao se trabalhar com coleções etnográficas de imagens presentes e passadas estamos operando no interior de uma convergência de imagens da qual a imaginação criadora do antropólogo participa intensamente em seu processo de fabricação de imagens como forma de narrar a cidade, dando a ela um continuum de consciência a si e a todos os outros nelas representados. Portanto, torna-se importante pensar a pesquisa com coleções etnográficas como integrando a investigação de uma etnografia da duração no âmbito dos estudos das praticas culturais no mundo contemporâneo e dos seus fluxos espaços-temporais.

Se em G. Durand, o método de convergência bergsoniano vem associado à noção de estrutura pelo caráter de dinamismo transformador que toda a imagem contempla, em termos das motivações simbólicas que ela carrega a forma que uma imagem adota, por outro lado, em termos de suas classificações em coleções, na pesquisa dentro do BIEV, ela dialoga, na direção dos estudos

\footnotetext{
${ }^{17}$ Cf. G. DURAND, L ímagination symbolique, Paris, PUF, 1992.

${ }^{18}$ Cf. artigo de C. ECKERT \& A.L.C da ROCHA, Prémisses pour une étude de la mémoire collective dans le monde contemporain sous l'optique des itinéraires des groupes urbains brésiliens. In: Socitétes, Revue des Sciences Humaines et Sociales. Demeures de 1'humain. Paris, França. DeBoeck Université, Vol. 75, 2002/1.
} 
de Michel Maffesoli e Pierre Sansot, com a dimensão dinâmica e aberta com que tais formas das imagens variam segundo as praticas culturais cotidianas presentes as sociedades humanas. Uma e outra abordagem das imagens, complementares entre si, concordam, entretanto, epistemologicamente, pois estrutura (figurativa) e forma são faces de uma mesma moeda que reúne o dado inteligível e dado sensível para o caso de um pensamento classificatório. As imagens como expressão de uma estrutura, para Gilbert Durand, estabilizada em certas formas segundo suas invariantes (operatórias diria, G. Vergnaud ${ }^{19}$ ), ou imagens portadoras de um formismo ou forma para Maffesoli ${ }^{20}$ e Sansot $^{21}$, respectivamente, porque compreendida na imediatez dos seus conteúdos empíricos, estamos aqui mergulhados nas categorias de imagens por meio da qual a imaginação criadora de um corpo coletivo configura, entre lembranças e esquecimentos, o espaço fantástico dos seus jogos de memória como possibilidade de perdurar no tempo.

\section{Da dispersão antropológica das imagens segundo sua matéria a convergência de seus sentidos}

O método de convergência, inspirado em Bergson e re-interpretado à luz de J. Piaget e G. Bachelard, como base do processo de classificação estrutural dos símbolos na obra de Gilbert Durand, rejeita, desta forma, a idéia tanto de teoria totalitária da infra-estrutura quanto da teoria da falta e da castração (cara a sociólogos e psicanalistas) para a interpretação do rico simbolismo das formas que as obras da cultura humana assumem no mundo. E é neste sentido que se proclama como um estruturalismo figurativo na medida em que as estruturas aqui mencionadas como chave interpretativa dos fenômenos sociais e culturais, compõem-se de uma forma transformável segundo protocolos motivados por grupos de imagens, elas próprias suscetíveis de se transformarem em estruturas mais gerais, denominadas por G. Durand, de regimes de imagens, segundo suas polaridades, noturno e diurno, o primeiro dividido em uma estrutura (esquizomórfica) e o segundo subdividido em duas estruturas (sintética e mística), cada uma gerando distintas categorias de imagens com seus cortejos de símbolos específicos e modalidades simbólicas de controle do tempo diversas e, ao mesmo tempo, complementares.

Para o caso do estudo com etnografia da duração para o estudo do patrimônio etnológico no interior da antropologia das sociedades complexas, a idéia das formas de uma imagem como portadoras de simbolismos diversos, aqui no caso, não significa a adoção pura e simples da

\footnotetext{
${ }^{19}$ Cf. G. VERGNAUD, no artigo A formação dos conceitos científicos, In: O fio e a rede do equilibrista, Porto Alegre, Ed.Geempa, 1993.

${ }^{20}$ Cf. P. SANSOT, Les formes sensibles de la vie sociale, Paris, PUF, 1986.

${ }^{21}$ Cf. M. MAFFESOLI, La connaissance ordinaire, précis de sociologie compréhensive. Paris, Librairie Méridiens, 1985.
} 
arquetipologia durandiana nos moldes empregados pelo autor, por exemplo, para seus estudos sobre mitoanálise ou mitocrítica ${ }^{22}$.

O que nos interessa em particular, desde o trabalho com coleções etnográficas para o estudo da duração é que o método de convergência re-interpretado por G. Durand, abarca um procedimento compreensivo de categorização das motivações simbólicas que orientam o microcosmo do semantismo das imagens no interior de uma narrativa, semantismo este sempre pluridimensional em razão a não linearidade do mundo dos símbolos e porque estruturante de todo o pensamento humano em seus esforços de enquadrar suas experiências subjetivas no mundo objetivo (telúrico, meteorológico, social, cósmico, etc.) no interior de uma duração, de um continnum de espaçotempo.

Muito especialmente, o método de convergência em H. Bergson, retomado por G. Durand, traz a tona, portanto, a discussão acerca das formas de se atingir a compreensão da complexidade do real considerando as regiões diversas da experiência humana em que aquele que pretende a compreensão deste real se situa. Em termos concretos, este método, no plano dos estudos de Antropologia visual e sonora do BIEV e de suas preocupações com a pesquisa com memória coletiva, itinerários urbanos e formas de sociabilidade no mundo contemporâneo nos possibilita operar com um conjunto amplo de imagens (sonoras, visuais, escritas, etc.) reunidas num mesmo ambiente, através das novas tecnologias digitais e eletrônicas, na modalidade de coleções que, consteladas em núcleos organizadores de sentido, nos permite inferir um conhecimento acerca do fenômeno da duração que ali se apresenta.

No caso do BIEV, trabalhando há mais de 10 anos, com as tecnologias eletrônicas e digitais na pesquisa com a etnografia da duração, tal convergência de imagens provenientes de fundos de origens diferentes (antigas e recentes, fabricadas ou não pelos antropólogos em suas pesquisas ao longo deste período) no interior de um mesmo campo de pesquisa antropológica sobre a memória coletiva e o patrimônio etnológico no mundo contemporâneo, podem nos indicar, desde o ponto onde eles convergem, a direção mais próxima para a interpretação da dialética temporal que orientam tais fenômenos, ainda que de forma indireta, algo que seria de todo impossível se enfocássemos isoladamente as imagens ali reunidas. Assim, para a produção e geração de coleções etnográficas sobre o patrimônio etnológico de uma comunidade urbana qualquer, quanto mais constelações de imagens apresentarem desde um mesmo ponto de convergência, tanto mais direções para o antropólogo construir conhecimento sobre uma determinada ordem de fenômeno.

Por outro lado, pesquisar o fenômeno da memória coletiva a partir da produção e geração de coleções etnográficas de conjuntos documentais de imagens, através do encadeamento de símbolos

\footnotetext{
${ }^{22}$ Novamente aqui a referência são os trabalhos de G. DURAND Figures mythiques et visges de l'oeuvre, Berg International, Paris, 1979 e Beaux-arts et archéypes, Paris, PUF, 1989.
} 
e das motivações simbólicas que as orientam, torna evidente que este ato de pesquisa não pode ser uma obra sistemática de um pensador único uma vez que a pesquisa com a etnografia da duração se revela, ela própria, como integrando o patrimônio da humanidade. A produção e geração de coleções, a partir do método de convergência aqui descrito, comporta sempre adições, correções, subtrações e retoques no estudo das suas constelações, ações estas que são o fruto da colaboração de todos aqueles que produziram tais documentos, no passado e/ou no presente. A descoberta do isomorfismo das imagens responsáveis por sua polarização em categorias se dá a partir das correlações estabelecidas entre eles pela própria participação da imaginação criadora do antropólogo no sentido de suas formas seguindo o efeito de sua convergência em torno de um núcleo de significados, tomados em constelações, como um todo.

O que o método de convergência aponta, para o caso da antropologia interpretativista que adotamos para os estudos da etnografia da duração, é que compreender e interpretar os jogos da memória coletiva não se trata de admirá-los desde os olhos de um artista, ou fotografo, ou cronistas, ou cineasta, mas de questionar sobre o sentido desta obra na convergência com outras homologas a partir da trama de idéias que compõe o dinamismo criador que encerra suas formas e/ou estrutura. Trata-se de atravessar a aparência das formas de uma imagem para descobrir desde aí o seu sentido encoberto. Como diria H. Bergson, para compreender o ódio, é necessário ver o que é o ódio e para isto necessito aprender a vê-lo e a (re) conhecê-lo; para isto torna-se necessário ao etnógrafo retornar as imagens elas mesmas através das suas formas vividas nas quais elas se deixam ver e se apresentam. Neste sentido, afastando-nos de G. Durand, é com P. Sansot ${ }^{23}$ e M. Maffesoli ${ }^{24}$ que aprendemos que vagabundear no interior das formas das imagens, no fundo de suas aparências, desde onde elas nos atraem ou nos causam repulsa, é uma forma possível através das quais as homologias entre as formas de diferentes imagens podem aproximá-las desde um ponto comum de convergência através do qual a imaginação do etnógrafo, participando dos jogos da memória que tais formas carregam, se deixa aprisionar.

\section{Etnografia da duração, o fluxo das imagens e o tempo real}

Para a pesquisa antropológica nas modernas sociedades urbano-industriais, o método de convergência aqui abordado, e no que tange a etnografia da duração, alerta para a espessura do tempo real e da própria passagem no tempo para o caso da produção da representação etnográfica e

\footnotetext{
${ }^{23}$ Ver em particular esta expressão metodológica em 3 obras paradigmaticas de P. SANSOT, Le goû de la converstion, Paris, Desclée de Brouwer, 2003, Les gen de peu, Paris, PUF, 1992 e Poétique de la ville, Klinckieck, Paris, 1997.

${ }^{24}$ Cf. M, MAFFESOLI, La conquête du présent, 1979, Aux creux des apparences, Paris, Plon, 1990, La transfiguration du politique, Paris, Grasset, 1992.
} 
sua função na construção do pensamento antropológico tanto quanto na produção de conhecimento em Antropologia, algo já abordado por nós em outro artigo, já mais antigo ${ }^{25}$.

A etnografia da duração consistiria nos termos de uma pesquisa com coleções etnográficas, na descrição da sinuosidade das imagens cujas figurações abarcam o desenho do real e a gama de suas durações num corpo coletivo, e onde a inteligência narrativa do antropólogo joga no sentido contrario do imobilismo do fluxo das imagens, ou seja, em aderência a memória coletiva como espaço de expressão de uma função fantástica - algo já abordado pelas autoras ${ }^{26}$. Reconstruir a mobilidades das imagens desde as imobilidades das formas que elas assumem segundo as intimações dos ambientes psico-sociais, interpretar a estabilidade de suas formas na instabilidade das motivações simbólicas nas quais as imagens se originam, esta aí o desafio de se operar com a produção e geração de coleções etnográficas sob o ponto de vista dos estudos do imaginário durandiano. O método de convergência nos permite aceder ao fluxo das imagens (conquista adaptiva ou recusa motivadora) diante das censuras culturais sendo construído e reconstruído desde a sua imobilidade no interior de determinadas constelações, segundo seus respectivos núcleos de sentido. Pela ambigüidade fundamental que contempla toda a imagem simbólica é que as coleções são assim montadas e desmontadas segundo as ordens dos fluxos de sentido que as suas formas tecem entre si, e é neste processo que situa o trabalho do antropólogo em seu esforço de compreender o semantismo dos símbolos que as configuram.

Formar coleções etnografias de imagens, no caso de serem imagens de acervo, como resultado de uma etnografia da duração significa ultrapassar a analise sociológica ou historiográfica dos símbolos geralmente compreendidos desde os momentos históricos e as modalidades de trocas e relações sociais nas quais emergem, uma vez que suas formas escapam à consciência clara do corpo coletivo desde onde se originam. Neste contexto, formar coleções implica em se compreender o fluxo das imagens, anônimo e pré-subjetivo, espécie de lugar onde há continuidade e sínteses impessoais, desde a ruptura com a abordagem bergsoniana acerca das relações entre matéria e memória, para aderir ao tratamento teórico-conceitual do tema do tempo, pela via da duração, nos moldes do pensamento bachelardiano, ou seja, desde uma dialética temporal entre o tempo vivido e o tempo do mundo.

Vale lembrar que este mesmo dispositivo interpretativo no processo de montagem de coleções, pela via do método de convergência, se aplica para o caso das técnicas e dos procedimentos que cercam a pesquisa etnográfica e que darão origem as coleções etnográficas

\footnotetext{
${ }^{25}$ Novamente cito o artigo de C. ECKERT \& A.L.C da ROCHA, Prémisses pour une étude de la mémoire collective dans le monde contemporain sous l'optique des itinéraires des groupes urbains brésiliens. In: Socitétes, Revue des Sciences Humaines et Sociales. Demeures de l'humain. Paris, França. DeBoeck Université, Vol. 75, 2002/1.

${ }^{26}$ A respeito ver Cf. artigo de C. ECKERT \& A.L.C da ROCHA, A memória como espaço fantástico, GUIGOU, Nicolas (org). In: Trayetos antropologicos.1a ed.Montevideo : Editorial Nordan-Comunidad, 2007, p. 33-42.
} 
geradas pelo próprio antropólogo em seu trabalho de campo. O fluxo das imagens como parte integrante das formas de pensar o fluxo da vida social esta presente na forma como ocorre a produção da representação etnográfica no interior da construção do pensamento antropológico pela via da escrita ou dos recursos audiovisuais e, por derivação, nas formas de se ordenar o conhecimento antropológico em torno de uma linguagem, a da comunidade de antropólogos. $\mathrm{Na}$ montagem de uma coleção o semantismo das imagens comportam um sentido em seu fluxo cuja fonte pode ser inferida (e ainda que seja impossível localizá-las) precisamente por que as imagens expressam este trajeto complexo da adaptação-acomodação (esquemas) dos pensamentos daquele que as produziu ao mundo das coisas, do fenômeno captado (ao que A. Gell, veremos mais tarde, em suas interpretações da arte, descreve como protótipo).

Lembremo-nos que segundo G. Durand, são os esquemas que formam o esqueleto dinâmico da imaginação, e que nos aqui completamos imaginação este que e a sede do pensamento. Segundo este autor, o dinamismo do jogo das imagens e de seus reflexos é que se formam as configurações, as quais orientam o sentido do fluxo das imagens que aparecem e desaparecem, fazendo, inclusive, com que algumas imagens se imponham entre outras. Esta formulação de G. Durand supera a abordagem de H. Bergson para o caso do método de convergência, pois não se trata mais, aqui no caso, de se operar as imagens desde aquelas que seriam consideradas por este autor como lembranças puras, uma vez que seriam aquelas que possuiriam uma dimensão de anonimato, não correspondendo, portanto, a nenhuma das ações especifica da vida de uma pessoa. E o conceito de memória com a qual opera este autor que inviabiliza que ele pense ser este fenômeno uma instancia fundamental da construção da representação do real pelo caráter simbólico do pensamento que a sedia. Ainda que este ressalte a importância do fluxo das imagens como espaço puro de movimento, seu tratamento do tema das relações entre matéria e memória não atribuem autonomia as imagens no sentido destas se descarnarem do seu lugar de enraizamento para gravitarem desde o movimento do pensamento do devaneio que orientam os jogos da memória.

No jogo das imagens, nos seus fluxos e reflexos, a constatação da presença de isomorfismos dos quais resultam os esquemas, os arquétipos e os símbolos reunidos no interior de constelações estáticas e que G. Durand reconhece a existência de certos protocolos normativos de representações imaginárias, definidas e relativamente estáveis, agrupadas em torno de esquemas originais que denomina de estruturas. A forma se define por conter certa estática, a estrutura implica a presença de certo dinamismo transformador no interior da própria forma, atuando como protocolo motivador para um agrupamento de imagens, e suscetível de originar um agrupamento maior, denominada por ele de Regime, mas que não são oriundos de determinados traços característicos ou tipológicos de indivíduos, em particular, e menos relacionados às pressões históricas e sociais sobre tais 
indivíduos, uma vez que estas imagens atravessam os tempos e os espaços, se propagando ininterruptamente num corpo coletivo.

Este tema já foi objeto de escrita de artigos, em outro momento, em que procurávamos pensar este sistema dinâmico de símbolos, arquétipos e esquemas de propagação configurando o próprio olhar e a escuta do antropólogo na sua pratica de etnografia sonora e visual no contexto das modernas sociedades urbano-industriais. Mais do que a intenção de caracterizar uma cultura visual especifica da qual faria parte o antropólogo, ou de se circunscrever certa civilização da imagem onde o olhar e a escuta do antropólogo assim como suas sensações e percepções são domesticados no interior de determinadas modalidades de pressões sociais e históricas sobre a imaginação criadora, a intenção destes artigos era pensar este processo de propagação em termos das representações do outro que tais narrativas contemplam e que persistem no interior do próprio campo dos saberes e fazeres antropológicos no mundo contemporâneo. Nos termos durandianos, tratava-se de compreender o fundo mitológico (ou seja, agrupamento de esquemas) que tendem a orientar a pratica de produção de imagens e sons em Antropologia, suas doutrinas, suas filosofias e narrativas derivadas, e com as quais toda a produção de imagens neste campo de conhecimento necessita dialogar para adquirir a tão pretensa autoridade etnográfica. Não caberia aqui retornar a este assunto, mas apenas mencioná- $\operatorname{los}^{27}$.

Assim, retornando-se ao tema deste ensaio, a etnografia da duração como técnica de pesquisa que inspira a produção de coleções etnográficas na pesquisa do BIEV com itinerários urbanos e formas de sociabilidades esta dirigida a compreensão dos fluxos das imagens que narram as formas do viver o mundo contemporâneo, considerando-se seu acesso desde os jogos da memória coletiva que configuram as trajetórias sociais e as narrativas biográficas de seus habitantes.

Tal fluxo de imagens este associado ao campo transcendental que os jogos da memória desenham para as formas do viver a cidade, delimitada como espaço fantástico construído no cruzamento entre o tempo subjetivo e intransitivo, das lembranças, e o tempo do mundo. Se Bergson nos inspira com o tema do método de convergência, resgatado por G. Durand em seus estudos sobre o trajeto antropológico do Imaginário, no caso da etnografia deste fluxo de formas e imagens que constituem o campo dos estudos da etnografia da duração é em G. Bachelard que vamos encontrar inspiração. Em H. Bergson, o fluxo das imagens e seu campo transcendental é anônimo, pré-subjetivo, impessoal, espécie de lugar onde há continuidade e sínteses tendo em vista sua própria concepção da matéria do tempo no interior do fenômeno da memória, em si mesma, involuntária. Com G. Bachelard, a dialética do tempo se dá na dialética da duração, nos arranjos

\footnotetext{
${ }^{27}$ Ver a propósito ver C. ECKERT \& A L C da ROCHA, Filmes "de" memória, do ato reflexivo ao gesto criador. In: Campos. Revista de Antropologia Social. Universidade Federal do Paraná. PPGAS/UFPR. Curitiba, Paraná, n.4, 2003 e Les enjeux de la ville moderne. In: Filmer la ville. Besançon/ França : Presses Universitaires Franc-Comtoises, 2002 , por exemplo.
} 
tecidos entre em entre o tempo vivido e o tempo do mundo, e onde os jogos da memória apelam para a estética das formas das lembranças, reminiscências e recordações.

Para o caso do método de convergência, temos aqui algumas particularidades, nesta releitura bachelardiana, pois o sentido do fluxo das imagens nos jogos da memória participam das suas formas enquanto acontecimento do e no mundo numa acomodação-assimilação constante destas formas a um ou mais objetivos e intencionalidades daquele que re-memora. Trata-se de um processo no interior do qual se situa a produção de imagens pelo próprio etnógrafo no jogo das formas nas quais molda as suas lembranças do encontro etnográfico a medida que transcorre sua pesquisa de campo. Assim também ocorre em termos da produção da representação etnográfica através de imagens no interior da construção do pensamento antropológico e, por derivação, nas formas de se configurar o conhecimento antropológico do outro desde esta dialética temporal.

O encontro/desencontro/confronto etnográfico se compõe no interior deste trajeto complexo que coloca o etnógrafo e o outro no interior de uma dialogo cultural especifico e onde as imagens participam das suas formas de acontecimento. Na etnografia da duração, a montagem das coleções etnográficas em termos do sentido do fluxo que carregam as imagens e suas formas, em termos de registro audiovisual, seja o produzido pelo antropólogo, seja pelo "outro" nativo, trata deste desafio de inferir a fonte das imagens desde onde elas se formam considerando-as como processo de adaptabilidade do pensamento ao mundo das coisas.

Inspirando-se aqui nas pesquisas pós-piagetianas sobre a participação das imagens na construção da inteligência e dos processos de conhecimento (e onde situamos os jogos da memória), considera-se assim que toda a direção das imagens produzidas pelo pensamento detém certo fluxo, no sentido de que pela geratividade, se dá desde certas regras de ação, dirigida ao conhecimento do real e a partir da construção de invariantes operatórias, onde a imagem, na sua relação da memória com a matéria, contempla schèmes. Diferente dos esquemas, resultantes das invariantes operatórias (expressão cunhada por G. Vergnaud) desde onde as imagens se estabilizam em determinadas formas em detrimento de outras, schèmes, referem-se ao caráter de generalização dinâmico e afetivo da imagem associados às motivações simbólicas que atuam inconscientemente do processo de fabricação de imagens no âmbito da construção do conhecimento. Nos schèmes reside o dinamismo da imaginação criadora do pensamento humano que promove, nos jogos da memória, os processos de re-investimento simbólico de imagens em certas formas que derivam para outras, e assim sucessivamente, se impondo ou não umas às outras, indo ou não, encontrar certo ponto de invariância tendo em vista o caráter operatório do pensamento em sua tentativa sonhar o interior da matéria das coisas. 


\section{O semantismo dos símbolos e a busca de invariantes nas formas da imagem}

Atribuindo-se a esta "pureza" das lembranças as marcas de invariâncias das imagens, descarnadas de seus atributos operatórios, (na direção dos estudos de J. Piaget, M. Denis ${ }^{28}$ e G. Vergnaud), abdicando de uma abordagem fantasmagórica da imagem para a produção do conhecimento desde os jogos da memória (e aderindo aos estudos de G. Durand e G. Bachelard sobre a imaginação), o ponto de invariância no interior de um fluxo de imagens contempla não apenas a presença de esquemas na suas origens, mas de schèmes uma vez que não se reduzem apenas a memória social, oficial ou histórica de uma dada sociedade, marcada por um tempo e um espaço determinado, mas gravitam desde o movimento do pensamento coletivo em direção à matéria das coisas afetadas pelo tempo.

Operar no plano de uma etnografia da duração com coleções etnográficas significa reunir os conjuntos de imagens no interior de núcleos de sentido desde o semantismo dos símbolos de que são portadoras suas formas, atentos a uma arqueologia de tais formas mais do que a sua cronologia, seguindo a sobreposição e as compensações das formas entre si em razão da pedagogia de certas imagens em relação a outras, fazendo-as deslizar, em termos durandianos, entre formas latentes e formas patentes. Neste processo, obtém-se assim uma vasta constelação de imagens reunidas segundo núcleos de sentido no interior de uma bacia semântica conformada pelo consenso de sentido que guardam entre si.

Importante se interromper o fluxo dos pensamentos neste momento para podermos lançar mão das idéias de outro autor cujas reflexões sobre as formas (dos objetos da arte ou objetos de arte) acabam convergindo para o mesmo espaço de problemas que estamos tratando aqui de delimitar. Alfred Gell em suas reflexões a respeito da definição do campo de uma pesquisa em antropologia da arte e em suas intenções de aproximar as possibilidades interpretativas da arte no interior das sociedades humanas, fora das questões da arte etnográfica das coleções de museus, enfrentou um desafio semelhante na interpretação de tais objetos. Seu trabalho foi o de consolidar um método de investigação para campo da antropologia da arte no contexto da teoria antropológica clássica, sem cair nas armadilhas do relativismo histórico-cultural para o qual os objetos artísticos são pensados, por exemplo, como parte das diferentes formas de ver (ways of seeing) dos sistemas culturais aos quais pertencem. Embora não seja a preocupação deste autor a construção de uma teoria antropológica das imagens e das formas dos objetos artísticos, nem a forma de agrupá-los em conjuntos documentais (museográficos, nos termos dos museus etnográficos) suas reflexões apontam, em inúmeras passagens de sua obra Art and Agency, para uma problemática que, ao final, resulta similar a que estamos tratando aqui. Ou seja, do tratamento interpretativo das diferentes

\footnotetext{
${ }^{28}$ Cf. M DENIS, Les images mentales, Paris, PUF, 1979 e Representation imagée et activité de mémorisation, Paris, Editions du CNRS, 1975.
} 
obras da cultura humana desde a preocupação do sentido das formas expressivas que elas adotam sem, contudo reduzi-las aos fenômenos sociais desde onde são geradas. Uma das primeiras aproximações que nos interessa aqui neste ensaio trata da preocupação de A. Gell ao assinalar os desafios de seu projeto intelectual em relação às marcas dos estudos de sociologia da arte (envolvendo parâmetros institucionais da produção, recepção e circulação da arte), das abordagens da semiótica da arte etnográfica (a arte como parte de uma linguagem gráfica de signos, não separada de uma linguagem visual) ou das teorias antropológicas dos estudos transculturais de estética (as preferências estéticas no interior dos sistemas culturais), faz referencia a dois aspectos essenciais da marca dos estudos antropológicos strictu sensu, quais seja, o caráter biográfico dos fenômenos que procura investigar, onde a perspectiva do tempo das próprias ações dos grupos humanos num determinado espaço.

Para A. Gell ${ }^{29}$, o contexto concreto dos ritmos contidos nas series biográficas que encerram as diferentes fases do ciclo da vida dos grupos humanos é que traz a perspectiva do tempo como fundante da compreensão das obras humanas no interior de uma dinâmica social de interações condicionado pelo que chamamos de cultura. Uma abordagem supra-biográfica nos encaminharia para a perspectiva histórica, uma abordagem infra-biográfica nos encaminha para a psicologia. No corpo de sua teoria antropológica da arte, não por acaso, este autor deriva para o estudo a imagem das formas dos objetos artísticos para compreender o contexto relacional por eles tecido no interior das suas sociedades de pertença.

O estudo deste autor sobre a arte pode ser aqui resgatado como fator importante para se ampliar o estudo das diferentes formas (latentes e patentes) das imagens, em termos de seus simbolismos, reunidas numa coleção através do método de convergência. Preocupado com universalismos redutores, A. Gell, descarta a possibilidade da estética como um parâmetro universal de descrição cultural ou comparação uma vez que seria supor que todas as culturas formulam este principio, sendo por esta via comparáveis entre si. Trata-se de situar a arte no interior das características de um objeto de pesquisa para as teorias antropológicas sobre as manifestações sociais das trocas simbólicas e não apenas das teorias da cultura ou das propriedades estéticas dos objetos, configurado no corpo das trocas simbólicas onde eles surgem e se propagam. Objetos de arte não tem uma natureza intrínseca, pois expressam significados simbólicos, e ainda que parte constituinte da linguagem, não se reduzem a uma linguagem visual. Os objetos artísticos, as obras de arte ou os trabalhos artísticos são índices (index), coisas desde a qual podemos inferir ou capturar outras, mas cujo sentido e intenção para ser compreendido necessita determinado suporte daquele que o interpreta, não podendo ser deduzido a sua significação por quaisquer leis que lhe

\footnotetext{
${ }^{29}$ Cf. A GELL, Art and agency, na anthropological theory, Oxford, Oxford University Press, 1998.
} 
sejam próprias. Para se inferir os significados (operação cognitiva) de um objeto necessitamos compreender-lo acessando uma determinada convenção de linguagem. $\mathrm{O}$ autor reconhece, assim, a presença indiciática de motivações simbólicas (expressão usada por nos) na forma das imagens que emanam deste, as quais dependem para acessá-las, da observação de algumas convenções semióticas consolidadas na natureza das relações sociais que este objeto cria no mundo da praticas culturais, não estando o seu sentido nem na coisa em si nem nas relações sociais, senão no valor simbólico que comporta.

Segundo as observações de A. Gell para o caso dos estudos de antropologia da arte, os esquemas de inferências empregados para se acessar tais objetos (índices) colocam em pauta os signos indexicais das disposições e intenções das trocas sociais, portanto, se configurando como agencias, mais especificamente, agencias sociais. Agencias não porque são efeitos de algo, mas, precisamente ao contrario, porque veiculam algo, são portadores de sentido das relações e interações por onde circulam. Neste ponto, todo objeto comportaria um traço indiciático (restaria a pergunta como a imagem e a forma do objeto contribuiriam para a sua conformação como índice) que se traduz como agencia de alguém ou de algo.

Ora, o traço indiciático que caracteriza todo o objeto (índice), e em especial, o objeto da arte (objeto artístico) não reside na natureza em si deste objeto (lembre-se de que A. Gell não pretende cair nas armadilhas dos estudos de filosofia da estética, menos ainda em uma abordagem fenomenológica - o que aqui nos interessaria), mas em algumas de suas propriedades, capturadas desde suas formas, as quais remeteriam certas significados acordados (através de convenções de linguagem construídas desde as relações e interações sociais que eles agenciam).

A noção de agencia cunhada por A. Gell se torna aqui fundamental para se pensar como este autor procura compreender a força simbólica dos objetos (expressão jamais empregada por ele para situar a atmosfera que deles emanam, sediada em suas imagens e suas formas) em termos deles possuírem o atributo de serem portadores de intenções, valores, aspirações, etc.. Ainda que citando Mauss e o Ensaio da Dádiva, o autor evita o conceito de símbolo para compreender como um objeto provocaria sequiências causais de um tipo particular de interação social (exercitando, assim, sua condição de agencias). Os objetos como agencias são tomados aqui como fonte e origem de acontecimentos mais do que consequiências destes. Todo o objeto como agencia, e aqui, certamente por seu valor simbólico, seria assim fonte e origem de acontecimentos no mundo dos eventos reais, mais do que descreveria formas de pensar abstratas. Para este autor, bonecas, ídolos e esculturas se equivalem no sentido de que remete a instancia arquetípica (interessante o emprego deste termo, nesta altura da explanação de seu argumento) do tema da antropologia da arte pela forma como entre as coisas e as pessoas se configuram as relações sociais. 
Mais interessante ainda se tornam estes comentários quando transladados para o caso dos documentos resultantes dos usos dos recursos audiovisuais no trabalho de campo para o caso do valor atribuído a tais artefatos tanto para o antropólogo quanto para algumas populações por eles pesquisadas em termos deles serem agencias do acontecimento etnográfico propriamente dito. $\mathrm{O}$ que A. Gell afirma para os objetos de arte nos permite compreender uma das máximas da antropologia compartilhada proposta por Jean Rouch, desde seu encontro com Edgar Morin, de que o cinema verdade e a verdade do cinema, ou seja, a os efeitos sobre as interações sociais com a introdução de uma câmera de filmar, com som sincronizado, no interior das trocas sociais que ali se processam. Os equipamentos audiovisuais como artefatos (index) atuando como agencias sociais, tendo em vista os objetos deles resultantes, investiriam de um sentido particular as interações sociais por eles retratadas, tendo em mente a civilização da imagem desde onde se situam. Objetos provocam acontecimentos atuando como agentes em situações sociais especificas, e elas se relacionam as disposições características de determinadas entidades. Uma pintura, por exemplo, e um index, criação de um artista (agente, na medida em que apreende algo daquele que a fez e agencia porque provoca acontecimentos no plano das interações sociais), portanto, esta pintura conduz esta para alguém, neste sentido sempre se pode pensar para um agente um paciente. Novamente aqui o autor quase insinua o conceito de símbolo, mas o evita. Alem de portar algo do artista, todo o objeto em segundo lugar em sua destinação constitui-se desde um recipiente, espaço para sua recepção. Finalmente, para se pensar os objetos de arte desde sua imagem e sua forma, no plano de uma antropologia da arte, A. Gell, ressalta a importância de se pensar a presença do modelo e esquemas (protótipo) reconhecíveis no interior das formas visuais dos objetos, responsáveis.

A esta altura deveríamos retornar ao tema da montagem das coleções sob o enfoque do método de convergência. Voltamos à afirmação de que as imagens podem ser reunidas em torno de certos núcleos de significação, formando constelações, tendo em vista a ótica do sentido e da direção de seus fluxos. Esta afirmação ainda que pareça conter traços de uma metafísica transcendental não opera com este nível de interpretação. O fluxo das imagens segue as orientações de um pensamento que tem por desafio operar o conhecimento o mundo real, o mundo empírico, neste sentido, pode-se pensar as imagens e suas formas desde sua geratividade, ou seja, a partir da compreensão de certas regras de ação adotadas por aqueles que a produziram e que esta dirigida ao conhecimento do real a partir da construção de invariantes operatórias. Neste ponto, a imagem de algo (objeto ou pessoas) e suas formas contempla schèmes tanto quanto esquemas, e esta é uma das razoes pela qual se pode pensar o seu fluxo. 
Mas antes de passarmos para outro autor que pode contribuir para este debate que estamos levantando no momento, torna-se importante se retomar algumas das afirmações de G. Durand sobre o tema de seu método de convergência agora no plano de seus estudos de mitocrítica e mitoanálise. Do ponto de vista da mitocrítica, operar com a etnografia da duração a partir do método de convergência na construção de coleções etnográficas trata-se de buscar através de um processo compreensivo que contempla toda a narrativa das imagens aquilo que é inerente a significação de todo a narrativa em si mesma. Nos termos de G. Durand estruturas, historia ou ambiente sócio-histórico assim como as pulsões psíquicas dos indivíduos é indissociável e fundam o campo compreensivo de toda a obra da cultura humana, tanto quanto a arte ou a narrativa literária. Neste sentido, cada seqüência de um vídeo, de um filme, quanto de um pintura ou conto esta carregado de um núcleo de sentido determinado e vem associado a um cenário cultural de uma época, ou seja, a um universo mítico desde onde se forma o "gosto", de onde emerge a leitura e onde se situa a compreensão do leitor.

Aplicando-se, ate certo ponto, o tema da mitocrítica para o caso da formação de coleções etnografias a partir de documentos fotográficos, videográficos, sonoros e escritos, teríamos que a abordagem de toda a obra perseguiria três temporalidades distintas: [1] reconhecimento dos temas e motivos redundantes que compõe a sincronicidade mítica da forma da imagem; [2] compreensão das situações ou combinatórias das situações que configuram, nas formas que desenham as imagens, o conjunto da obra (cenário, personagens, ações, situações, etc.) e, por ultimo, [3] a analise de tais formas em outras épocas e espaços culturais bem determinados se faz confrontando a especificidade do momento cultural da obra com o momento de sua leitura e a situação do próprio leitor origina assim um "Atlas" delimitado de situações precisas onde as imagens exalam núcleos de sentido associados as suas estruturas profundas, sendo por isto mesmo re-investidas de sentido constantes e repetidos ao curso da historia de uma mesma cultura.

Aqui o espaço como fantástica transcendental de que fala G. Durand quando abordamos o tema da memória coletiva ${ }^{30}$ e a pesquisa no interior da produção e geração de coleções etnográficas $^{31}$ são aqui fundamentais para se compreender o sentido e a direção de tais reinvestimentos constantes e repetidos em certas formas de se narrarem mitos, lendas, estórias e historias - numa ressurgência de imagens - no interior de uma mesma cultura (brasileira, africana,

\footnotetext{
${ }^{30}$ Ver a respeito ECKERT, C. \& A L C da ROCHA O Infra-Ordinário na Paisagem Urbana como Condição da Produção de Etnografias Sonoras e Visuais, apresentação, In: XXVIII Encontro Anual da ANPOCS, São Paulo, mimeo.In: Fórum de Pesquisa 15: Antropologia (audio)visual e das imagens: meios do fazer (novos suportes), modos de fazer (métodos), objetos de estudo e formas reflexivas (teorias). XXIV RBA, 2004, Recife.

${ }^{31}$ A propósito ver os trabalhos apresentados por ECKERT, C. \& A L C da ROCHA, Banco de Imagens e Efeitos Visuais: Escrituras hipermidiáticas e as metamorfoses da escrita etnográfica In: Coloquio Internacional "Imagen y Ciencias Sociales”, Repensando investigación y sociedad en Latinoamérica, 2004, Buenos Aires; Escrituras hipermídiaticas e as metamorfoses da escrita etnográfica em hipertexto. In: XXIX ENCONTRO ANUAL DA ANPOCS, 2004, Caxambu.
} 
ameríndia, grega, etc.), atravessando, numa longa duração, suas temporalidades peculiares e, inclusive, contradizendo a temporalidade do mito do Progresso. Gêneros, estilos, gostos, modas respondem a fenômenos de concentração de imagens em determinadas formas as quais detém o poder de narrar os dramas vividos pela humanidade no interior de uma época ou de um meio cósmico e social determinado, dando-lhe direção e sentido as suas transformações. No interior deste espaço de produção, geração e transmissão de imagens através de formas é que a etnografia da duração se situa como parte dos estudos sobre memória coletiva, principalmente, quando seus jogos compõem-se com a agitação espaço-temporal das modernas sociedades complexas, acentuando-a ou nuançando-a, sem obedecer a determinismos culturais.

Neste ponto, vamos evocar os estudos de G. Vergnaud sobre a teoria dos campos conceituais onde este autor aprofunda a noção de schème $e^{32}$ particularmente interessantes para se pensar este aspecto da invariância mencionado tanto por A. Gell quanto por G. Durand, em particular ao refletir sobre esta invariância construída desde o caráter operatório da representação que se encontra no processo de construção de pensamento conceitual. Para o autor nos processos de construção do conhecimento onde a representação ocupa lugar central, as invariâncias se originam não dos objetos, mas das relações que construímos em relação a ele, e isto pode nos auxiliar para pensar as bases de nossa própria construção teórica sobre o lugar das homologias entre as imagens como parte da montagem de coleções etnográficas no interior da pratica da etnografia da duração.

Segundo G. Vergnaud as invariantes operatórias operam no interior de classes de situações a partir das quais as operações de pensamento, extraindo do mundo dos fenômenos uma propriedade, uma relação ou um conjunto de relações (as quais modelizam uma determinada classe de situação e desde onde podemos pensar no protótipo de A. Gell e nos schèmes de G. Durand). A intenção clara do autor e a de ultrapassar o conceito de schème tal qual concebido por J. Piaget que enfocava mais sob o ponto de vista de uma totalidade dinâmica organizada no interior da representação e da construção do real. Os esquemas operatórios estabelecem uma diferenciação mais precisa entre o significado e o significante para a construção da representação além de acrescentar o componente das motivações, emoções e das percepções como variáveis intervenientes no processo de formação de conceitos. Segundo G. Vergnaud, as invariantes operatórias são o núcleo duro da representação sem as quais nem as inferências, nem as predições (de que tanto falava Bergson em seu método de convergência), nem mesmos os significados tem sentido. As invariantes operatórias superam as idiossincrasias das formas de pensar dos indivíduos (suas experiências singulares e suas

\footnotetext{
${ }^{32}$ Algo que já expresso pelo pensamento kantiano: Tout ce que nous pouvons dire c'est que l'image est un produit du pouvoir empirique de l'imagination productrice, et que le schème des concepts sensible comme des figures dans l'espace est un produit, en quelque sorte un monogramme de l'imagination pure à priori, au moyen duquel et suivant lequel les images sont d'abord possibles, et que ces images ne doivent toujours être liées au concepts qu'au moyen du schème qu'elles désignent et auquel elles ne sont pas entièrement adéquates (E. KANT, Critique de la raison pure, Paris, PUF, 1967, p.153)
} 
representações do vivido), e muito embora estejam referidas ao movimento pulsional do pensamento em direção ao mundo das coisas e dos objetos, expressam significados reconhecidos socialmente e dirigidos para uma comunicação.

No âmbito de sua teoria dos campos conceituais, este autor também atribui um papel para as inferências no processo de construção do conhecimento, entretanto alerta para o fato de que elas se constroem por decorrências de proposições, sendo estas ultimas que nos permitem pensar, em ultima instancia, a causa e as conseqüências dos fatos. Diferentemente de Bergson que pensava da inferência a partir da intuição, G. Vergnaud assinala a inteligência como sede dos mecanismos de inferências os quais possuem duas fontes de origem possíveis: endógenos que constituem os schèmes, as regras de ação e as representações e a outra fonte, os elementos do real que participam do funcionamento do schème, mas que são exteriores ao sujeito e que o alimentam. Na formulação do pensamento conceitual pela via de inferências se observa que as invariantes (operatórias dada na organização de cadeias associativas) comportam alguns componentes fundamentais tais como a materialidade, as estruturas e as significações (sentidos privados e sentidos sociais). Sob o aspecto funcional, as inferências abarcam a formulação de julgamentos e do pensamento simbólico inconscientes e implícitos que escapam a linguagem estruturada.

\section{A produção do pensamento e o lugar da imagem}

Pelo viés da interpretação durandiana do tempo, desde os estudos da dialética da duração e na poética do devaneio na obra de G. Bachelard, o método de convergência aplicado ao processo de produção, geração e circulação de coleções etnográficas parte de alguns dos apontamentos de $\mathrm{H}$. Bergson a respeito do reconhecimento da profundeza das imagens, mas não se restringe a eles. Num apelo aos estudos de J. Piaget a respeito da construção do símbolo para o caso do nascimento da inteligência na criança e os estudos bachelardianos sobre a imaginação criadora e a sua fantástica transcendental no plano da memória como um espaço fantástico, atinge-se a possibilidade de se compreender a representação do espaço que contempla toda a imagem (ocularidade, profundidade e ubiqüidade), suas relações projetivas e suas funções simbólicas de reserva infinita de eternidade contra o tempo, nos termos de G. Durand.

Neste sentido, toda a imagem não é contemplação do mundo, mas resulta de uma transformação dos objetos no mundo, retirando-os de sua indiferença. Se criar imagens, mentais ou não, é pensar o mundo através de uma transformação na sua matéria, tem-se que fabricar imagens configura-se ontologicamente como uma operação no tempo. O método de convergência, segundo G. Durand, numa releitura de H. Bergson, postula a existência de uma semantismo de imagens, as quais contem materialmente um simbolismo que lhe é inerente desde seus lugares de geração e 
produção e que, ao final, tratam do tema da poética humana de superar as devastações que a matéria perecível do tempo lhe provoca. Espécie de anti-destino, o Cogito humano encontra-se submetido as leis desta expressão criativa que se traduz como imaginário, recurso supremo da consciência, e contra a qual nenhuma objetividade alienante pode prevalecer.

A primeira conseqüência importante de tais comentários é a definição do símbolo como anterioridade tanto cronológica quanto ontológica de toda a produção, geração, circulação de imagens, mentais ou técnicas. Sob o plano do símbolo também se situa toda a linguagem humana cuja estruturação simbólica está na origem de todo o pensamento, cientifico ou não. O simbolismo de que é portadora toda a imagem é o que assegura uma universalidade a todos os processos sociais e culturais que se situam no plano da fabricação das imagens.

A segunda remete ao conceito de trajeto antropológico cunhado por G. Durand, onde o autor sinaliza que, no plano do imaginário, há uma incessante troca entre as pulsões subjetivas e assimiladoras e as intimações objetivas do meio cósmico e social, do que resulta a idéia de uma gênese recíproca entre os gestos pulsionais humano e o ambiente material e social que o cerca e as imagens, mentais ou não, como parte das acomodações do sujeito ao seu meio objetivo. O simbolismo das imagens sempre obedeceria, assim, as pressões e intimações do meio aos imperativos biopsíquicos do ser-no-mundo.

Neste novo contexto, o método de convergência cunhado por H. Bergson, toma outro vulto. Um método tanto pragmático quanto relativista de observar a convergência de vastas constelações de imagens, mais ou menos estáveis e regulares, estruturadas por certo isomorfismo de símbolos. (DURAND, 1984, p. 33)

De H. Bergson tanto quanto de J. Piaget e A. Leroi-Gourhan ${ }^{33}$, G. Durand retira alguns aspectos relevantes de suas teorias para repensar o tema da convergência de imagens desde um isomorfismo de símbolos que elas são portadoras. Ou seja, o reconhecimento de um acordo, no plano da imaginação criadora, entre os gestos do corpo (as dominantes posturais), os centros nervosos e as representações simbólicas, o qual esta na origem das constelações simbólicas em torno de certos núcleos de significação. Conforme seu mestre, G. Bachelard, G. Durand reconhece que cada gesto (posturais, digestivos e rítmicos) convoca uma matéria e uma técnica, suscitando um material imaginário, senão um instrumento, pelo menos utensílio.

\section{A imagem e suas formas: a galáxia dos jogos da memória}

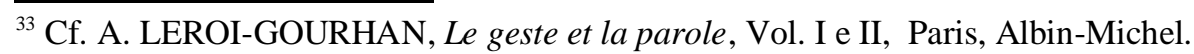


O que se esta pleiteando aqui é o reconhecimento, no plano do método de convergência e da pesquisa com coleções etnográficas, do que M. Denis ${ }^{34}$ denomina o status cognitivo intrínseco ao processo de fabricação de toda a imagem técnica por ela já ter se construído anteriormente como imagem mental, distinta das percepções daquele que a produziu, pela função figurativa que toda a imagem contempla. As imagens técnicas, por seu turno, e mesmo as imagens verbais que não são equivalentes figurativos do real, não sendo simples prolongamento da percepção daquele que a produz nem mesmo uma forma residual das sensações vividas no momento de sua captação, resulta das atividades simbólicas de um pensamento que esta operando conhecimentos e que, ainda que comporte sentidos privados e sociais, esta marcado pela autonomia que caracteriza os trabalhos da imaginação.

No corpo das reflexões aqui adotadas sobre a imagem e os estudos de memória coletiva e patrimônio etnológico toda a imagem conserva em sua forma as pistas dos gestos, intenções, motivações e das ações daquele que a fabricou tanto quanto apela para os processos da imaginação criadora daquele que a contempla. Não estamos sendo nem um pouco esotérico (nem exotérico neste ponto, bem ao contrario, no plano dos estudos de sociologia das formas, honramos aqui uma tradição de pesquisa clássica orientada pela obra de G. Simmel e N. Elias). Por outro lado, na busca de compreender o status cognitivo da imagem para o caso de coleções etnográficas como parte de uma etnografia da duração, nos interessa pensar uma sistemática de compreensão das formas do tempo que toda a imagem contempla desde sua gênese na obra de um individuo do qual muitas vezes resulta um acervo de imagens.

Segundo Simmel, as ações e os estados de consciência nas diferentes sociedades podem ser compreendidas a partir das formas e dos arranjos as ações de conjunto que a constituem segundo seus efeitos de agregação. Para este autor uma forma traduz efeitos de agregação sem os quais a vida social não poderiam se desencadear, e cujas cadeias causais apela os encadeamentos históricos de ações recíprocas entre os indivíduos e (ou) grupos. Para Simmel ${ }^{35}$ tais conjuntos de ações recíprocas acumulados e entrelaçados no tempo se constituem como a vida históricas, um tecido conjunto complexos de fenômenos cujas causas (mais formais do que materiais) podemos compreender através de um exercício analítico, num exercício de regressão sem fim, sem que jamais se atinja a compreensão de suas primeiras. A compreensão da vida histórica obtida através do estudo da vida das formas detém elementos eles próprios não explicáveis por uma razão histórica uma vez que os próprios sistemas explicativos compõe-se de elementos não observáveis ou seja, de conteúdos da consciência.

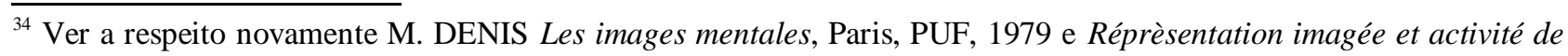
mémorisation, Paris, Editions du CNRS, 1975.

${ }^{35}$ Cf. G. SIMMEL, Les problèmes de la philosophie de l' histoire. Paris, PUF, 1984.
} 
Ao observarmos a natureza das imagens mentais ou não, pela via dos estudos do pensamento e da inteligência, veremos que inúmeros autores reconhecem que seu status cognitivo advém do fato dela mesclar as dimensões do individuo, da cultura e da sociedade em suas diversas instancias, numa gênese recíproca. Não supõe apenas aos aspectos perceptivos, motores e sensoriais dos indivíduos implicados na sua construção, como vinculam tais aspectos as situações e acontecimentos sociais nas quais as ações e intenções deste individuo se situam. Por outro lado, se reconhece que a imagem se relaciona tanto ao caráter pratico da inteligência, nem sempre imitativos dos signos, quanto a sua dimensão discursiva, de puras significações desde a função simbólica desde onde ela se origina, ou seja, a da imaginação criadora. Segundo H. Wallon ${ }^{36}$, a imagem escapa a ordem dos objetos e das coisas atuais e imediatas para imaginar o mundo das coisas seja no passado, seja no futuro.

Tais efeitos de agregação das ações recíprocas nos quais repousam as formas podemos pensar aqui com algumas aproximações ao método de convergência pensado por G. Durand, desde a idéia inicial de $\mathrm{H}$,. Bergson, com os estudos simelianos das representações dos conteúdos da consciência indiretamente projetados nas imagens. Em Simmel, não é necessário se deter o rigor de um depoimento ou testemunho para se acessar os estados de consciência desta ou daquela cultura, pois as suas formas de expressão remetem a sua dimensão de vivido humano. As situações onde os interesses e as preferências dos indivíduos e (ou) grupos podem ser analisadas e reconstruídas, num procedimento analítico em espiral, observando-se os efeitos de agregação que eles atingem no interior de uma dada sociedade.

A ordem física de uma forma, capturada por uma imagem (mesmo a mental) apenas tem como referencia a matéria vivida de uma experiência humana, não podendo ser confundida com ela. Mas e somente na forma dada de uma matéria que esta modalidade de vida se torna possível. Portanto, poderíamos dizer com G. Simmel, que há uma dimensão formal na pesquisa com coleções etnográficas a partir do método de convergência pois através do estudo das formas da vida humana, segundo ele, é que se pode atingir a compreensão do seu caráter social. As formas (e as imagens, diríamos) afetam os grupos humanos, unindo-os ou separando-os uns dos outros. Não se trata aqui, com G. Simmel, de reduzir o semantismo dos símbolos que veiculam as imagens as formas oriundas das pressões de determinados ambiente psico-sociais, mas de pensar a vida social não só

\footnotetext{
${ }^{36}$ Segundo H. WALLON, Les origines de la pensée chez l'enfant. Paris, PUF, 1975, p. X-XII, as condutas materiais são substituídas pelas condutas verbais (condutas da ordem das pulsões) que transformam o desejo em olhar para um determinado objeto, jogando com este objeto, pela via do imaginário, por vezes a serviço de interesses implícitos e inconscientes, mas que exigem, sempre um ajuste rigoroso com as significações dos dados da experiência assim como com as significações entre elas, logo, desde um contexto social e cultural onde aquele que pensa se encontra situado. Para H. WALLON, o conhecimento possível de um pensamento transcorre desde as influencias sociais e tecnológicas das quais o seu esforço especulativo é solidário.
} 
como derivada das leis próprias da associação humana (unité sui generis) segundo suas razoes singulares, mas dependente da energia da vida das formas e do semantismo que elas expressam.

Com G. Simmel, podemos observar, através do método de convergência, a autonomia das formas sociais, sua unidade singular e sua independência das ações isoladas dos indivíduos e (ou) dos grupos sociais, ou seja, como fenômeno coletivo, mais que o somatório das inteligências individuais. As formas sociais se tornam fonte de pesquisa dos problemas da continuidade da vida coletiva (o que apontaríamos aqui para o tema da memória coletiva) diante do fluxo perpetuo dos indivíduos. As preocupações deste autor com as formas sociais e as dimensões espaço-temporais na configuração de uma unidade para a vida social e a conservação da vida coletiva são aqui relevantes de serem acionadas para que se consiga reter o quanto a sua obra acrescenta aos estudos sobre memória coletiva e patrimônio etnológico no mundo contemporâneo.

Aproximando-se aqui as preocupações simmelianas com a vida das formas e o método de convergência, que podemos pensar os isomorfismos dos schèmes e dos símbolos (e nem tanto dos arquétipos, aqui nos distanciado da arquetipologia durandiana) no interior de sistemas de constelações de imagens, dos quais resultam a montagem de coleções etnográficas (desde a etnografia da duração) e espaço interpretativo onde se pode, finalmente, compreender a existência de certos protocolos normativos estáveis na configuração das formas das imagens reunidas em um acervo, agrupados em torno de esquemas os quais dão origem, por sua vez, ao que G. Durand denomina as estruturas.

Partindo das imagens desde seu processo de domesticação no interior de determinadas pressões sociais e históricas (na linha dos estudos como os de A, Manguel, Lendo Imagens; B. Kossoy, Fotografia e Historia; P. Burke, Testemunha ocular, por exemplo ${ }^{38}$ ), a etnografia da duração propõe o estudo das imagens que conformam o universo psíquico, social e cultural do próprio antropólogo, das imagens que ele consome, das imagens do outro e de sua cultura que o atravessam e das imagens o constituem, e que, por isto mesmo, lhe escapam. Etnografia dos arranjos temporais que presidem os jogos da memória, os quais aproximam o pensamento do antropólogo às formas de pensar dos nativos na medida em que ambos encontram-se habitados por imagens, submetidos ao sistema dinâmico de símbolos e de schèmes, cujas formas daí derivadas tendem a ser arranjar na modalidade de narrativas, engendrando narrativas lendária ou históricas, mitos e doutrinas religiosos, sistemas filosóficos, etc.

Através do estudo das formas pode-se compreender a fidelidade das imagens a certos gestos daquele que as produziu e as suas respectivas motivações simbólicas, oriundas do encontro de suas

\footnotetext{
${ }^{38}$ A respeito ver B. KOSSOY, Fotografia e História. São Paulo, Ateliê Editora, 2001, BURKE, P. Testemunha ocular. São Paulo, EDUSC, 2004 e MANGUEL, Alberto. "O espectador comum. A imagem como narrativa”. In: Lendo Imagens. São Paulo, Cia das Letras, 2000.
} 
pulsões individuais com os constrangimentos do meio cósmico e social. Em se tratando de um estruturalismo figurativo que investe na compreensão do dinamismo criador da imaginação, tal forma ao adquirir um caráter estático não abdica do dinamismo transformador interno (reconhecido por todos os autores aqui mencionados) que a une a outras imagens, sendo suscetível de ser reagrupada desde um outro lugar, a partir da transfiguração de sua forma inicial em outra, motivada pelo conjuntos de traços que marcam a vida daquele que a produziu tanto quanto a do corpo coletivo ao qual pertence, e no interior das pressões históricas e sociais vividas por ambos.

\section{A imagem mental e seus equivalentes materiais figurativos (desenhos, fotografias, vídeos) o corpo e a experiência, a percepção e a imaginação}

$\mathrm{O}$ conhecimento em antropologia como alias em outras áreas das ciências humanas se caracteriza por captar dados (etnográficos) desde duas fontes, através de todo um processo empregado pelo antropólogo para a categorização do mundo cósmico e social cuja cultura pretende investigar. Uma das fontes de dados "empíricos" a ser categorizado e organizado segundo categorias interpretativas do campo antropológico propriamente dito são das palavras ditas, enunciadas e ouvidas em campo da boca de nossos informantes, em referencia ao corpo vivo da letra vivida, aquela pronunciada desde seu lugar de enunciação, no interior das formas de vida cotidiana. Esta letra viva que será transmutada em letra morta, no espaço livresco de diários, notas, monografias, teses e dissertações, os quais que remetem sempre, em termos epistemológicos, ao estudo dos problemas da língua e da linguagem em termos das distinções e das diferenças reúnem os antropólogos e os grupos e/ou comunidades por eles pesquisados e cujos contextos do encontro/desencontro etnográfico são essências de serem remontados, no texto a ser escrito, para se estabelecer a compreensão daquilo que a antropologia afirma a respeito de suas sociedades e culturas.

A descrição desta experiência em termos de imagens literárias (escritas) e técnicas (fotografia, vídeo, filme, sons) no âmbito de estudos monográficos, ensaios fotográficos, livros, vídeos ou filmes documentários, teses, dissertações, etc.guarda, neste sentido, por si mesmo problemas de uma abordagem hermenêutica e fenomenológica, ainda que nem todos os antropólogos queiram tratar de tal assunto em suas reflexões sobre a metodologia de pesquisa em Antropologia. Em particular quando esta experiência é descrita desde um ponto de vista fortemente subjetivo, enraizado na pratica concreta do vivido etnográfico e toda uma gama de aspectos de ordem sensível e que somente a experiência da consciência da imersão da cultura do outro nos permite acessar. 
Para o caso dos estudos de etnografia da duração é fundamental que o antropólogo pense a pratica etnográfica como parte desta estrutura transcendente da consciência que persegue a temporalidade e a espacialidade toda a experiência em campo e sua tradução no interior de sua comunidade lingüística de origem. Em especial, no caso da pratica etnográfica a partir da produção, geração e circulação de imagens sonoras, escritas ou visuais esta experiência se torna um dos eixos fecundos de estudos e pesquisas em torno da representação etnográfica empregadas pelos antropólogos para compreender as culturas e sociedades diferentes das suas de origem e que, com o passar do tempo, no mundo pós-colonial, é parte integrante dos jogos da memória destas mesmas sociedades e culturas para a fabricação de suas identidades culturais no devir.

A construção de categorias e os estudos comparados de civilizações nos legou um patrimônio interessante de obras (a produção da Escola Sociológica Francesa é exemplar, de Mauss a Lévi-Strauss, passando por Durheim) sobre este problema e o tema da representação do real, os quais não queremos assim adentrar, mas apenas mencionar para deles retirar alguns pontos. Um deles se referem aos comentários de H. Wallon, sobre a noção de categoria como fenômeno ajustável mais ou menos as coisas tais quais elas são realmente ou, desde aí, como fenômeno interpretado desde sua significação funcional, isto é, por sua capacidade de agrupar os objetos segundo suas relações dependendo das situações em que estes objetos, seres e coisas se encontram na vida social. Interessaria aqui os comentários deste autor principalmente quando este assinala que as categorias constituem essencialidades do pensamento na construção de relações, sendo portanto, dinâmicas e obedecendo a um processo de trans-formação interno indistinto das trans-formações das condições históricas e sociais onde nascem (o grafismo destas palavras é nosso), mesclando-se também as formas do entendimento e as formas de sensibilidade. A construção de categorias é indispensável, portanto para todo o processo de conhecimento sendo matéria de julgamento sobre os fatos, os seres e as coisas e as unidades que os ligam entre si, pois o conhecimento humano não aprecia a realidade tal qual ela é em seu estado bruto, indiferente, indistinto. O que nos leva a ressaltar, com este autor, que a produção e geração de coleções etnográficas para o caso de uma etnografia da duração não trata da simples classificação de imagens em coleções cada vez mais amplas e gerais que remeteriam as coisas registradas ou captadas, mas a pesquisa do simbolismo das imagens no interior de núcleos de significações, sem reduzi-las ao meio físico e social de onde se originam. Sob o plano da representação etnográfica ao invés de procura nas formas das imagens os elementos concretos das situações que as originaram, investigar o simbolismo que elas engendram no corpo de uma narrativa.

Portanto, as imagens captadas e registradas das culturas e sociedades e as suas formas de transposição para a nossa própria sociedade e cultura contemplam, assim, concepções que permitem 
a consciência do antropólogo atingir um ponto de vista desde o qual pode contemplar não somente seu objeto-sujeito de pesquisa, mas suas próprias formas de conhecimento. Para o caso da pesquisa com a etnografia da duração e os procedimentos decorrentes dos trabalhos de montagem de coleções etnográficas, a formação de conceitos por parte do antropólogo participa intrinsecamente de sua imersão no jogo das imagens e das suas formas como parte da descrição dos jogos que a memória realiza em seus desafios de assimilar-acomodar a matéria perecível do tempo.

A experiência etnográfica no âmbito de uma etnografia da duração resulta da adesão do antropólogo a este dinamismo criador das imagens em formas que se transfiguram em outras formas e que não lhe é de todo consciente, mas se torna consciente precisamente por este trajeto de produção, geração e circulação de coleções de imagens, reunidas em torno de núcleos de significações, dos quais emergem diferentes formas em razão do semantismo dos símbolos a elas associados. Numa coleção, os pólos de constituição dos núcleos de significações em torno dos quais as imagens se constelam é movente por sua própria natureza de schèmes, o que significa que uma imagem ao ser produzida con-forma (forma algo com) o mundo social, atribuindo a experiência ordinário e do banal algo de extra-ordinário, uma vez lhe investe uma significação a mais, retirando-a da simples indiferença do ser-no-mundo.

A produção/geração de imagens para a prática da etnografia da duração representa um aspecto importante de procedimento de pesquisa, pois permite ao dado etnográfico desprender-se da vida vivida que lhe deu origem e integrar um fluxo de imagens e formas cuja movência é por excelência seu universo de compreensão. Neste ponto, a imagem construída da experiência etnográfica na sua condição de representação possui esta peculiaridade de transcender o concreto vivido do corpo do antropólogo desde seu encontro/desencontro com outras culturas e sociedades, adquirindo autonomia de expressão em si mesma.

A obra de Anna Grimshaw (The ethnographer's eyes) sobre as formas de ver e de conhecer da antropologia moderna na área da produção audiovisual do conhecimento antropológico é neste caso paradigmática do que pretendemos assinalar. Os usos da câmera e do microfone em experimentos etnográficos no corpo do método etnográfico e das técnicas de trabalho de campo são tratados como parte do engajamento reflexivo do antropólogo no universo pesquisado tanto quanto revelam construções de assertivas da construção de um conhecimento especifico no campo dos saberes antropológicos. Enfocando-se esta obra do que já foi comentado acima, percebe-se claramente o esforço da autora em revelar o lugar da câmera e do microfone como parte das cadeias operatórias do pensamento de certos antropólogos, cada um conforme suas adesões teóricas e conceituais, no seu esforço de compreender a cultura e a sociedade do outro a partir da organização de suas imagens visuais e sonoras em cadeias associativas de sentido capazes de traduzir este outro 
para sua comunidade lingüística de origem. O caráter observacional do qual resultam tais imagens remete tanto a razão quanto a sensibilidade de cada antropólogo, em conformidade com os recortes teóricos e conceituais nos quais se alinham, no seu encontro etnográfico com o outro nos termos de uma experiência visual intensa na sua sociedade e cultura.

A menção de A. Grimshaw ${ }^{39}$ a uma sensibilidade cinemática do antropólogo em campo (cinematic sensibility) e as formas de ver dos etnográficos delas derivadas e as questões da mis-enscène desta experiência do campo como um dos princípios básicos da sua re-apresentação através da escritura audiovisual nos convida a pensar a produção de imagens sonoras e visuais como parte do mergulho corpóreo do etnógrafo numa dada ordem social e cultural o qual necessita acomodar e assimilar as formas de percepção e de ação anteriormente construídas por ele no interior de sua própria cultura e sociedade de origem.

Sob este ângulo, D. Macdougall traz importantes contribuições para se pensar o lugar do corpo, do gênero, dos gestos, das emoções e dos sentidos do antropólogo como importantes elementos da construção da descrição etnográfica para o conhecimento antropológico, oferecendo a representação visual e as formas de conhecimento não-verbais um importante campo de estudos de suas formas de pensar. Para este autor o caráter figurativo da imagem, ou os traços analógicos implícitos da representação visual, no jogo de seu fundo de sentido permitem levantar importantes questões a problemática das propriedades do pensamento antropológico fabricar conhecimento uma vez que o controle do sentido na escrita percorre caminhos mais tortuosos (algo que é discutível considerando que a escrita contribui com outra forma de se processar o conhecimento antropológico e que sua comparação com outros suportes incorreria no erro de considerá-los como instancias cujo funcionamento sejam similares). As características da representação visual que todas as imagens produzidas pelos antropólogos (alias como a de quais quer outros seres humanos) se processaria a partir do lugar do visual nas formas de conhecimento produzidas pela antropologia e do próprio campo da antropologia visual as quais orientam a mente e o corpo do etnógrafo para aquilo que vê no momento de suas interações durante o trabalho de campo com o sistema simbólico complexo de outras sociedades e culturas. Embora D. Macdougall atribuam a imagem fílmica (fotografia e escrita) uma força de sentido especifica, pela função simbólica que engendram as imagens figurativas no interior dos atos de pensamento, evocam qualidades táteis e sensoriais (texturas, cores, movimentos, sons, temperaturas, etc.) dos objetos e das coisas, sua corporeidade e materialidade, apresentando-os como uma experiência socialmente compartilhadas. Em sua obra The Corpareal image, film, ethnography and the senses ${ }^{40}$, este autor reconhece, em termos da

\footnotetext{
${ }^{39}$ Cf. A. GRIMSHAW The ethnographer's eqye, ways of seeing in Modern Anthropology. Cambridge, Cambridge University Press, 2003.

${ }^{40}$ Cf. D. MACDOUGALL The Corpareal image, film, ethnography and the senses, Princenton, Princenton University Press, 2006.
} 
relação intersubjetiva que a origina, a complexidade visual da imagem (pela qualidade simbólica daquilo que ela pretende registrar ou capturar na sua existência física), muito especialmente no caso da pesquisa antropológica por conter varias dimensões de uma interação: gestos, expressões faciais, falas, movimentos corporais etc.

Este aspecto, como já salientamos, foi apontado por H. Bergson quando alude, em seu método de convergência, às relações que a imaginação criadora tece entre a matéria e as suas imagens-vestígios. Numa etnografia da duração toda a imagem produzida, assim como suas formas, traduz no próprio instante de sua fabricação uma imagem envelhecida, construída para alem daqueles e daquilo que a gerou. Este desprendimento da imagem do meio físico e social que lhe deu origem se compreende em razão da função simbólica que toda a imagem, técnica ou mental, detém, engendradas nas interfaces de duas estruturas fundamentais da inteligência humana, a da consciência, de ordem lógica, e a do inconsciente, de ordem dramática, conforme nos insiste os estudos de Sara Paín (A função da ignorância), e que alguns autores pensaram como seja como processo de deslocamento da inteligência pratica a inteligência teórica (nos termos de $\mathrm{H}$. Wallon), ou de desenvolvimento cognitivo da fase operatória a dialética (nos termos de J. Piaget), etc.

A captação de uma imagem através de uso de dispositivos técnicos, sejam quais forem, não escapa a este principio que esta na base até mesmo da fabricação das imagens mentais como parte integrante da função transcendental que orienta o dinamismo criador da imaginação humana. Mais que se debruçar sobre os processos internos de construção das imagens, o estudo com os jogos da memória que orientam a pesquisa com a etnografia da duração as imagens fabricadas por tais dispositivos é captada desde o lugar privilegiado do corpo daquele que a produziu, seja antropólogo ou não, e de sua experiência, etnográfica ou não, numa dada situação, revelando-se desde aí sua pertença às temporalidades que encerram o seu próprio lugar junto a outros grupos humanos.

Portanto, a etnografia da duração no plano dos estudos sobre memória coletiva e itinerários urbanos se coloca, para o caso das pesquisas que desenvolvemos no BIEV, interior ao processo de produção de imagens pelo próprio antropólogo da e na cidade, desde o lugar que o seu corpo ocupa na experiência etnográfica e na sua relação direta com o outro bem como desde o lugar onde este se encontra no mundo cósmico e social. A produção de imagens pelo etnógrafo estaria aprisionada ao seu destino de origem, ou seja, a narrar mais da imagem da própria experiência etnográfica do antropólogo em campo conforme os arranjos da memória que elas guardam deste estar-junto-com o outro, em seu próprio ambiente cósmico e social.

Nos estudos da área da psicologia da inteligência, é reconhecido que o corpo não é, como afirmava H. Bergson, a condição de todas as condições do pensamento. Para H. Bergson, na teoria das relações entre a matéria do tempo e da vida e a memória, os traços mnésicos da matéria sobre o 
corpo, pela via da percepção, são responsáveis pelas imagens-vestígios que, em termos de geratividade (lugar de onde se originam) marcam a aventura singular destas impressões no reino da imaginação. Em H. Bergson, temos que a experiência é significativa para os arranjos da memória tendo em vista que ela nos revela o quanto a vida e a vida da consciência (a alma) esta associada a vida do corpo (da matéria). Ao apontar criticamente para o lugar experiência na fabricação das imagens e das suas formas no interior dos jogos da memória, este autor cria uma confusão entre corpo e organismo para os processos de construção de representação do real os quais abarcam a vida da consciência. A vida da consciência esta ligada ao corpo, em referencia ao simbolismo que toda a imagem do corpo como corpo contempla.

Esta é uma questão importante para o caso de pensarmos as relações das imagens e das suas formas durante o percurso da etnografia da duração estar, em termos da geração de conceitos sobre a experiência do antropólogo em campo, mais ou menos situadas no plano da ação ou no plano do devaneio. Ou se haveria planos intermediários que expressariam os graus de maior ou menor atenção a vida e a adaptação a realidade social ou cultural na qual se encontra imerso o antropólogo durante a etnografia.

Esta questão remete a se pensar o ato interpretativo que abarcaria o campo da produção da representação etnográfica pelos antropólogos como resultado do diálogo com o outro, mas agindo desde sua dupla experiência, da ação e do devaneio como parte da experiência etnográfica em si mesma. Uma experiência que para H. Bergson estaria referida a atenção sensorial e atenção motriz do antropólogo às situações de campo desde onde se desprenderia o campo interpretativo das ações, sensações, deslocamentos e movimentos das quais as representações etnográficas resultariam a partir de certas formas e não de outras. Já comentamos acima o quanto estes apontamentos de H. Bergson são restritos para se pensar o processo construção e interpretação de imagens, pois nos orientam a estabelecer uma polêmica entre o pensamento imediato (da ordem do senso comum, o não-clarificado e o irrefletido) e o pensamento refletido, ambos podendo ser re-interpretados em aderência ao pensamento de G. Durand e às suas criticas ao pensamento iconoclasta o qual pretenderia submeter o conhecimento do mundo dos objetos e das coisas a partir da total ausência das imagens. Ou seja, a partir do reconhecimento do principio da lógica da harmonia conflitual que agruparia estas duas modalidades (pensamento imediato versus pensamento refletido) de vida da consciência, surgiria um terceiro estado do pensamento fruto do equilíbrio antagonista entre ambos. Este foi o ponto que conduziu G. Durand a apontar os limites das teses de J-P Sartre e de H. Bergson sobre a imaginação e o imaginário, para se alinhar aos estudos de G. Barchelard, de J. Piaget e de A. Leroi-Gouhran em suas indagações sobre o lugar das imagens, da imaginação e do imaginário na construção do trajeto antropológico do qual resulta todo o conhecimento humano. 


\section{Imagens e a emergência da consciência}

Do que vimos comentando até o momento, resulta que o método de convergência aplicado aos estudos da memória coletiva e aos procedimentos de pesquisa por nós denominados de etnografia da duração, por dedicar-se ao estudo das modalidades de agenciamento do tempo no interior dos jogos da memória dos habitantes das modernas sociedades complexas (a partir de suas narrativas biográficas, de trajetórias sociais e dos itinerários urbanos) nos permite pensar que a emergência da consciência das descontinuidades do tempo e das transformações dos espaços urbanos entre eles esta intimamente relacionada à presença da imaginação criadora como condição dos processos de superação dos traços granulares e lacunares do tempo vivido pela via de um tempo pensando e refletido.

A emergência da consciência estaria aqui, na etnografia da duração, referida a condição do etnógrafo atingir a terceira potencia do Cogito apontados por G. Bachelard como condição de interpretação dos jogos da memória. A continuidade de um tecido temporal engendrado pelos jogos da memória, mais do que uma duração fornece uma ilusão de duração no domínio do real. A continuidade do tempo só é possível no plano de uma causalidade formal mais do que material, solidária da ação recíproca entre a duração vivida, sentida, narrada e a duração do mundo, vazia e abstrata.

E é neste contexto, portanto, que o estudo da duração se prolonga como estudo da propagação do tempo numa forma restituída por imagens sobrepostas e encadeadas segundo determinados ritmos a partir de isomorfismo, as quais, por sua ressonância, lhe conferem continuidade.

A participação da imagem e da imaginação neste processo de atividade formalizante dos jogos da memória, pelo estatuto cognitivo que ambas detém revela que os jogos da memória estabelecem uma sucessão ordenada, pela vida das formas, a vida da matéria para alem do que esta contempla. Para Bachelard. O Cogito cartesiano (Eu penso, logo existo), por sua horizontalidade, não poder ser a sede de uma consciência formal, uma vez que entre este eu e as coisas pensadas se estabelece um relação que vai da afirmação a confirmação. A existência do eu esta confrontada a sua experiência específica das coisas. Na expressão "eu penso que penso, logo existo", ao contrario, o Cogito se encontra liberado de suas descrição fenomenológico. Finalmente, no julgamento de existência "eu penso que penso que eu, penso, logo existo", o Cogito não pensa alguma coisa, mas se pensa pensando desde alguém que pensa, portanto, suas existências consecutivas aparecem em sua dimensão formalizante. 
No plano da etnografia da duração estamos situando o método de convergência como parte do estudo destas superposições temporais que fabricam um percurso de continuidade para a matéria perecível e lacunar do tempo. Tais sobreposições temporais se encontram no interior das constelações de imagens que a produção/geração de coleções etnográficas pretende acessar, não como copias ou duplos do real (no sentido museográfico atribuído as coleções), mas como parte de um espaço fantástico onde os acontecimentos do mundo se desprendem de sua matéria, e através das formas de um tempo pensado, se perpetuam, suplantando o tempo presente se projetando no interior do tempo futuro.

Pode parecer que retomamos o inicio deste artigo, mas o que estamos procurando ressaltar neste momento é a participação das imagens e dos símbolos neste processo da atividade formal que abarcaria o fenômeno da duração no interior de constelações. As constelações de imagens que se formam a partir de coleções etnográficas, liberadas de sua materialidade, apresentam a potencialidade de uma sucessão temporal pela causalidade formal que contemplam como forma de pensamento. Segundo M. Denis, o caráter construtivo da atividade imaginal é incontestável a partir do momento em que se almeja o grau de abstração e da esquematização da imagem em relação as experiências perceptivas. Para o autor, a construção de imagens não contem jamais todas as informações contidas na estimulação original; da mesma forma, a construção de imagens resulta da abstração de elementos privilegiados no interior da realidade percebida, mais do que as propriedades físicas dos objetos reais, são os elementos privilegiados por uma análise perceptiva que entram na construção de esquemas figurativos.

Novamente ressaltamos que para os estudos da etnografia da duração H. Bergson reconhece, no plano de seus estudos sobre matéria e memória, que toda experiência abarca o que ele denomina espaço interior que é, ao mesmo tempo, espaço de percepção externa. Para o autor, para se compreender todo esforço intelectual torna-se importante superar a simplificação do esquema de interpretação do ser-no-mundo desde a oposição dentro-fora ou superfície-profundidade. Segundo G. Durand, este autor parte da idéia da ausência deste antagonismo para, logo após, criar clivagens no interior das imagens no sentido escrutinar a elasticidade da duração submetendo-as sinuosidades de um real continuo e heterogêneo.

Retomando algumas das questões anteriores vemos que no método de convergência em H. Bergson o autor apóia-se na sua concepção de que a memória, pela via da percepção, é o ponto de contato entre a consciência e as coisas, entre o corpo e o espírito, e é seu interesse na compreensão da profundidade das imagens e suas formas que torna suas reflexões aqui importantes (matéria $e$ memória $^{41}$ ). Entretanto, para este autor (consciência e vida ${ }^{42}$ ), consciência que dizer seleção de

\footnotetext{
${ }^{41}$ Cf. BERGSON, H. Matiére et Mémoire. Essai sur la relation du corps à l'esprit. Paris, PUF, 1969.

${ }^{42}$ Cf. BERGSON, H. Essai sur les données immédiatess de la conscience. Paris, PUF, 1970.
} 
imagens uma vez que o que elas projetam para o ser para alem de si mesmas ofusca a sua própria ação no mundo ao mesclar o espaço exterior ao seu espaço interior. Segundo ele, o tempo do relógio constrangeria a consciência do tempo ao mesclar-se a realidade de um tempo interno, muito embora a consciência do tempo seja reduzida a esta pressão do tempo do mundo. A representação do tempo permanece algo referido a ação no mundo ( $A$ evolução criativa ${ }^{43}$ ), inseparável do movimento concreto do qual se origina, e a consciência, distinta da atividade do espírito, resultaria de um trabalho cerebral, dos neurônios, como atividade orgânica de adaptação a vida (bios).

Entretanto, nos termos do método de convergência, a etnografia da duração traz o problema do funcionamento das estruturas de representação simbólica através das imagens, que segundo M. Denis, obedecem à evocação imaginada sucessivas de um mesmo objeto num mesmo sujeito, caracterizando-se por níveis e graus diferenciais de abstração, tanto quanto correspondem a certos graus de variabilidade de conteúdos figurativos. A imagem conserva uma hierarquia de propriedades físicas dos objetos, de acordo com sua importância e especificidades relativas no que concerne a definição cognitiva de conceitos e a sua evocação mental, e segundo a probabilidade de alguns traços contribuírem para a formação circunstancial das imagens. Da hierarquia de certas propriedades físicas dos objetos reais se desprende certa ordem, definindo o relevo cognitivo das suas propriedades ao longo da apreensão perceptiva inicial e a probabilidade de uma imagem colocar em jogo os traços correspondentes dos objetos em atividades ulteriores da imaginação. A imagem pode restituir, num primeiro tempo, as características bastante gerais do objeto (abstração maximal), mas permanece possível, se for o caso, de acentuar a vivacidade ou a riqueza da imagem pela evocação dos traços suplementares, menos característicos, de um conceito evocado, mas que contribuem para a sua definição. Finalmente, segundo o autor a imagem tem a função privilegiada para a definição do conceito, como estrutura propícia ao reagrupamento unitário dos diferentes elementos que entram em jogo no processo de conceituação. Sendo que a intervenção dos processos imaginativos é facilitadora no tratamento de exemplos e, de forma distinta, na elaboração de conceitos.

Esta é uma das razões pelas quais, no método de convergência, a etnografia da duração a partir de coleções etnográficas, a posição precisa das imagens no interior dos acontecimentos, segundo um tempo uniforme, tem importância relativa pois, no plano da duração, não restitui a sua forma um sentido, o qual só pode ser obtido seguindo-se suas ondulações e ritmos.

Semelhante ponto de abordagem da emergência da consciência no interior dos jogos da memória e, por derivação, no estudo com coleções etnográficas, nos afastaria de H. Bergson, mais uma vez, pois para ele - autor do aqui mencionado método de convergência - a emergência da

\footnotetext{
${ }^{43}$ Cf. BERGSON, H. L'évolution créatrice. Paris, PUF, 1959.
} 
consciência como estado do pensamento não exigiria a superprodução de imagens, mas ao contrario, demandaria a subtração do excesso nas imagens que impediria por sua luminosidade toda a visibilidade. Diferente do que foi concebido por seu autor de origem, o método de convergência se trata de um processo especulativo por parte do etnógrafo no curso do qual escutando e registrando relatos e narrativas, vendo e captando imagens, extraem as suas formas do contexto que as gerou (geratividade).

O método de convergência situado no plano dos estudos antropológicos da memória e da duração no mundo urbano contemporâneo, ao contrario do que seu autor pretendia de integrar a memória na percepção, para daí pensar os pontos de contato entre a consciência e as coisas, pode nos levar a compreender as imagens e as suas formas como parte integrante do processo de construção da representação etnográfica, a qual reúne a um só tempo traços de objetividade e subjetividade uma vez que ela resulta da produção simbólica que preside todo o pensamento humano confrontado o mundo cósmico e social que o abarca.

Pelo viés da interpretação durandiana do tempo, desde os estudos da dialética da duração e na poética do devaneio na obra de G. Bachelard, o método de convergência aplicado ao processo de produção, geração e circulação de coleções etnográficas parte de alguns dos apontamentos de $\mathrm{H}$. Bergson a respeito do reconhecimento da profundeza das imagens, mas não se restringe a eles. Num apelo aos estudos de J.Piaget a respeito da construção do símbolo para o caso do nascimento da inteligência na criança e os estudos bachelardianos sobre a imaginação criadora e a sua fantástica transcendental no plano da memória como um espaço fantástico, atinge-se a possibilidade de se compreender a representação do espaço que contempla toda a imagem (ocularidade, profundidade e ubiqüidade), suas relações projetivas e suas funções simbólicas de reserva infinita de eternidade contra o tempo, nos termos de G. Durand.

Neste sentido, toda a imagem não é contemplação do mundo, mas resulta de uma transformação dos objetos no mundo, retirando-os de sua indiferença. Se criar imagens, mentais ou não, é pensar o mundo através de uma transformação na sua matéria, tem-se que fabricar imagens configura-se ontologicamente como uma operação no tempo. O método de convergência, segundo G. Durand, numa releitura de H. Bergson, postula a existência de uma semantismo de imagens, as quais contem materialmente um simbolismo que lhe é inerente desde seus lugares de geração e produção e que, ao final, tratam do tema da poética humana de superar as devastações que a matéria perecível do tempo lhe provoca. Espécie de anti-destino, o Cogito humano encontra-se submetido as leis desta expressão criativa que se traduz como imaginário, recurso supremo da consciência, e contra a qual nenhuma objetividade alienante pode prevalecer. 
A primeira consequiência importante de tais comentários é a definição do símbolo como anterioridade tanto cronológica quanto ontológica de toda a produção, geração, circulação de imagens, mentais ou técnicas. Sob o plano do símbolo também se situa toda a linguagem humana cuja estruturação simbólica está na origem de todo o pensamento, cientifico ou não. O simbolismo de que é portadora toda a imagem é o que assegura uma universalidade a todos os processos sociais e culturais que se situam no plano da fabricação das imagens.

A segunda remete ao conceito de trajeto antropológico cunhado por G. Durand, onde o autor sinaliza que, no plano do imaginário, há uma incessante troca entre as pulsões subjetivas e assimiladoras e as intimações objetivas do meio cósmico e social, do que resulta a idéia de uma gênese recíproca entre os gestos pulsionais humano e o ambiente material e social que o cerca e as imagens, mentais ou não, como parte das acomodações do sujeito ao seu meio objetivo. O simbolismo das imagens sempre obedeceria, assim, as pressões e intimações do meio aos imperativos biopsíquicos do ser-no-mundo.

Neste novo contexto, o método de convergência cunhado por $\mathrm{H}$. Bergson, toma outro vulto. Um método tanto pragmático quanto relativista de observar a convergência de vastas constelações de imagens, mais ou menos estáveis e regulares, estruturadas por certo isomorfismo de símbolos. (DURAND, 1984, p. 33)

De H. Bergson tanto quanto de J. Piaget e A. Leroi-Gourhan, G. Durand retira alguns aspectos relevantes de suas teorias para repensar o tema da convergência de imagens desde um isomorfismo de símbolos que elas são portadoras. Ou seja, o reconhecimento de um acordo, no plano da imaginação criadora, entre os gestos do corpo (as dominantes posturais), os centros nervosos e as representações simbólicas, o qual esta na origem das constelações simbólicas em torno de certos núcleos de significação. Conforme seu mestre, G. Bachelard, G. Durand reconhece que cada gesto (posturais, digestivos e rítmicos) convoca uma matéria e uma técnica, suscitando um material imaginário, senão um instrumento, pelo menos utensílio.

\section{Referências}

BACHELARD, G. La terre et les rêveries de la volonté. Paris, José Corti, 1988.

BACHELARD, G. La dialectique de la durée. Paris, PUF, 1963.

BACHELARD, G. La poétique de l'instant. Paris, PUF,

BACHELARD, G. La terre et les revêries du repos. Paris, José Corti, 1988.

BERGSON, H. L'évolution créatrice. Paris, PUF, 1959.

BERGSON, H. Matiére et Mémoire. Essai sur la relation du corps à l'esprit. Paris, PUF, 1969.

BERGSON, H. Essai sur les données immédiates de la conscience. Paris, PUF, 1970.

BERGSON, H. La pensée et le mouvant. Essais et conférences Paris, PUF, $1969 b$.

BURKE, P. Testemunha ocular. São Paulo, EDUSC, 2004.

DENIS, M. Les images mentales, Paris, PUF, 1979.

DENIS, M. Representation imagée et activité de mémorisation, Paris, Editions du CNRS, 1975.

DURAND, G. Beaux-Arts et archétypes, la religion de l'art, Paris PUF, 1989.

DURAND, G. Figures mythiques et visages de l'oeuvre. Paris, Berg International, 1979. 
DURAND, G. Les structures anthropologiques de l'imaginaire, Paris, Dunod, 1984.

DURAND,G. L'imagination symbolique, Paris, PUF, 1992

ECKERT, C \& ROCHA , A.L.C da. O tempo e a cidade. Coleção Academia II. Porto Alegre, Ed. da UFRGS, 2005.

ECKERT, C \& ROCHA, A LC da. Banco de Imagens e Efeitos Visuais: Escrituras hipermidiáticas e as metamorfoses da escrita etnográfica In: Coloquio Internacional “Imagen y Ciencias Sociales”, Repensando investigación y sociedad en Latinoamérica, 2004, Buenos Aires; Escrituras hipermídiaticas e as metamorfoses da escrita etnográfica em hipertexto. In: XXIX ENCONTRO ANUAL DA ANPOCS, 2004, Caxambu.

ECKERT, C \& ROCHA, A LC da. Filmes "de" memória, do ato reflexivo ao gesto criador. In: Campos. Revista de Antropologia Social. Universidade Federal do Paraná. PPGAS/UFPR. Curitiba, Paraná, n.4, 2003.

ECKERT, C \& ROCHA, A LC da. Les enjeux de la ville moderne. In: Filmer la ville. Besançon/ França : Presses Universitaires Franc-Comtoises, 2002.

ECKERT, C \& ROCHA, A LC da. O Infra-Ordinário na Paisagem Urbana como Condição da Produção de Etnografias Sonoras e Visuais, apresentação, In: XXVIII Encontro Anual da ANPOCS, São Paulo, mimeo.In: Fórum de Pesquisa 15: Antropologia (audio)visual e das imagens: meios do fazer (novos suportes), modos de fazer (métodos), objetos de estudo e formas reflexivas (teorias). XXIV RBA, 2004, Recife.

ECKERT, C \& ROCHA, A LC da. O tempo e a cidade. Coleção Academia II. Porto Alegre, Ed. da UFRGS, 2005.

ECKERT, C \& ROCHA, A LC da. Prémisses pour une étude de la mémoire collective dans le monde contemporain sous l'optique des itinéraires des groupes urbains brésiliens. In: Sociétés, Revue des Sciences Humaines et Sociales. Demeures de l'humain. Paris, França. DeBoeck Université, Vol. 75, 2002/1.

ECKERT, C \& ROCHA, A LC da. A memória como espaço fantástico, GUIGOU, Nicolas (org). In: Trayetos antropologicos.1a ed.Montevideo : Editorial Nordan-Comunidad, 2007, p. 33-42.

G. DURAND, Les structures anthropologiques de l'imaginaire, Paris, Dunod, 1984

GELL,A. Art and agency, na anthropological theory, Oxford, Oxford University Press, 1998.

GRIMSHAW, A The ethnographer's eqye, ways of seeing in Modern Anthropology. Cambridge, Cambridge University Press, 2003.

KANT, E. Critique de la raison pure, Paris, PUF, 1967.

KOSSOY, B. Fotografia e História. São Paulo, Ateliê Editora, 2001.

LEROI-GOURHAN, A Le geste et la parole, Vol. I e II, Paris, Albin-Michel.

MACDOUGALL, D The Corpareal image, film, ethnography and the senses, Princenton, Princenton University Press, 2006.

MAFFESOLI, M. La conquête du présent, 1979.

MAFFESOLI, M. Aux creux des apparences, Paris, Plon, 1990.

MAFFESOLI, M. La connaissance ordinaire, précis de sociologie compréhensive. Paris, Librairie Méridiens, 1985.

MAFFESOLI, M. La transfiguration du politique, Paris, Grasset, 1992.

MANGUEL, A Lendo Imagens. São Paulo, Cia das Letras, 2000.

PAIN, S. A função da ignorância, Porto Alegre, Artes Médicas, 1999.

PIAGET, J. A construção do real na criança

PIAGET, J. A formação no símbolo na criança,

PIAGET, J. O nascimento da inteligência na criança, Rio de Janeiro, Zahar Editores, 1970.

PIAGET, J. Introdução a psicologia genética e Filosofia, ilusões da sabedoria. In: Os Pensadores, Ed. Abril, São Paulo, 1978.

SANSOT, P. Les gen de peu, Paris, PUF, 1992.

SANSOT, P. Le goû de la converstion, Paris, Desclée de Brouwer, 2003.

SANSOT, P. Les formes sensibles de la vie sociale, Paris, PUF, 1986.

SANSOT, P. Poétique de la ville, Klinckieck, Paris, 1997.

SIMMEL, G. Les problèmes de la philosophie de l' histoire. Paris, PUF, 1984.

VERGNAUD, G. A formação dos conceitos científicos. In: O fio e a rede do equilibrista, Porto Alegre, Ed.Geempa, 1993.

WALLON, H. Les origines de la pensée chez l'enfant, Paris, PUF, 1975. 